\title{
Contracts and Exits in Venture Capital Finance
}

\author{
Cumming, Douglas J.
}

Document Version

Final published version

Publication date:

2002

License

CC BY-NC-ND

Citation for published version (APA):

Cumming, D. J. (2002). Contracts and Exits in Venture Capital Finance. LEFIC. Center for Law, Economics and Financial Institutions. LEFIC Working Paper No. 14

Link to publication in CBS Research Portal

\section{General rights}

Copyright and moral rights for the publications made accessible in the public portal are retained by the authors and/or other copyright owners and it is a condition of accessing publications that users recognise and abide by the legal requirements associated with these rights.

Take down policy

If you believe that this document breaches copyright please contact us (research.lib@cbs.dk) providing details, and we will remove access to the work immediately and investigate your claim. 


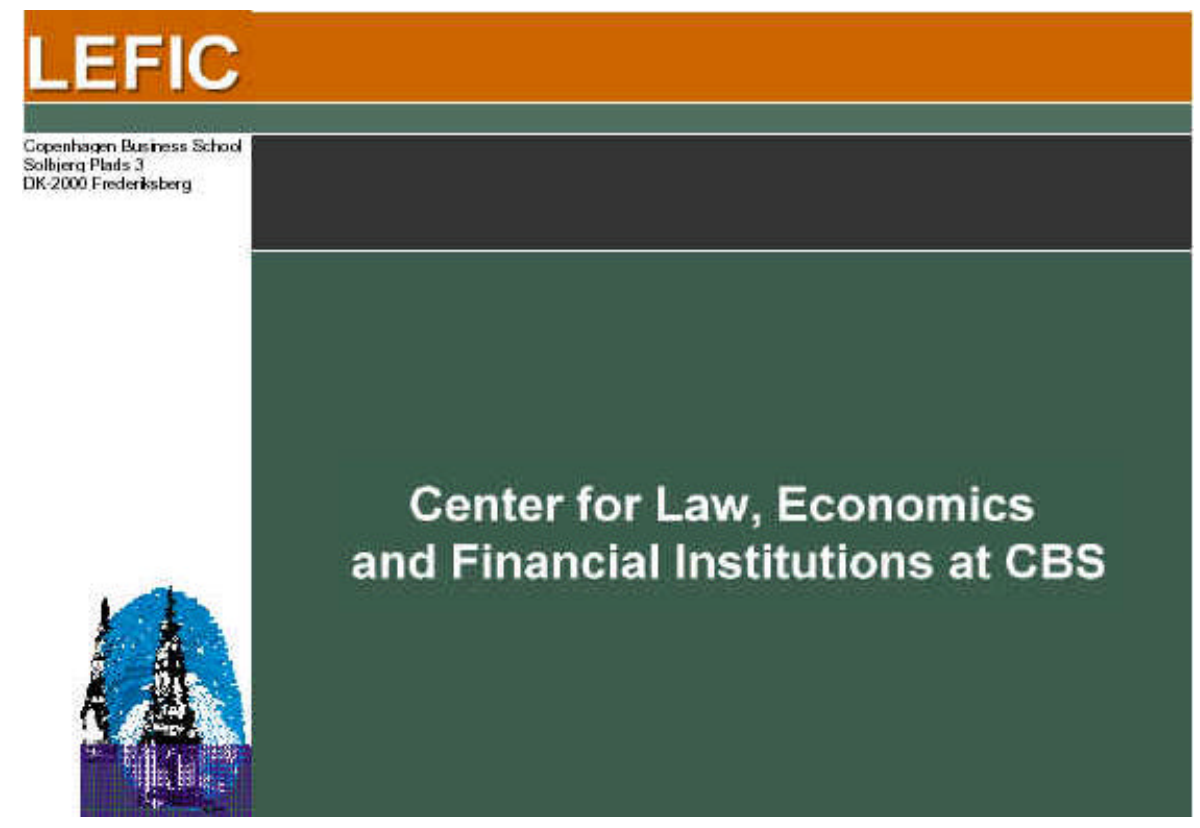

LEFIC WORKING PAPER 2002-14

Contracts and Exits in Venture Capital Finance

Douglas J. Cummings

Copenhagen Business School

October 2002

www.cbs.dk/LEFIC 


\title{
CONTRACTS AND EXITS IN VENTURE CAPITAL FINANCE*
}

\author{
Douglas J. Cumming \\ Assistant Professor of Finance, Economics \& Law \\ University of Alberta School of Business \\ Edmonton, Alberta, Canada T6G 2R6 \\ Telephone: (780) 492-0678 \\ Fax: (780) 492-3325 \\ E-mail: douglas.cumming@ualberta.ca \\ Web: http://www.bus.ualberta.ca/dcumming/
}

First Draft: March 1, 2002

This Draft: October 3, 2002

* I owe special thanks to the venture capital funds for providing the data, and to Jan Peter Kooiman, Enrico Perotti, Ibolya Schindele, and Robert Westenberg for their helpful support. I received helpful comments and suggestions from the seminar participants at the Aarhus Business School (March 2002), Copenhagen Business School (March 2002), the ABN AMRO Bank Conference on Venture Capital Exit Strategies, Amsterdam (March 2002), and the University of Alberta (April 2002). This paper is scheduled for presentation at the American Finance Association Annual Conference, Washington DC (January 2003). Collection of the data was made possible with the generous assistance of the ABN AMRO Bank Corporate Finance Department, the University of Amsterdam Department of Financial Management, and a University of Alberta Pearson Fellowship. I have also greatly benefited from working with Jeff MacIntosh on related research. Any errors and/or omissions are my own. 


\title{
CONTRACTS AND EXITS IN VENTURE CAPITAL FINANCE
}

\begin{abstract}
Contracts and exits from a sample of 179 investment rounds in 132 entrepreneurial firms by 17 European venture capital (VC) funds are analyzed. The data indicate the financial contracts are quite heterogeneous in terms of both the cash flow and control rights. The use of different securities by European VC funds does not depend on the definition of venture capital, and the securities used are not functional equivalents. A normative empirical analysis of exit shows the likelihood of different types of exit vehicles (IPO, acquisition, and liquidation) and the returns to venture capital depend on not only firm specific characteristics but also the allocation of cash flow and control rights.
\end{abstract}

Keywords: Venture Capital, Financial Contracting, Exit, IPO, Acquisition

JEL Classification: G24, G28, G31, G32, G35 


\section{INTRODUCTION}

Venture capital ${ }^{1}$ contracts are heterogeneous: there exist differences across contracts in the selected securities, control rights, veto rights, provisions for different contingencies, among other things, depending on the characteristics of the transacting parties. Venture capital exit decisions are also heterogeneous: a disposition may involve an initial public offering (IPO), or an acquisition (i.e., a trade sale, where both the entrepreneur and venture capitalist sell their interest), and venture capital contracts typically specify which party has control over the exit decision. ${ }^{2}$

It is widely recognized that a venture capitalist's decision to invest in an entrepreneurial firm is based on exit potential. While previous research in venture capital has identified international differences in financial contracts and international differences in exit strategies, the precise interaction between these two activities has not been empirically studied. This paper introduces a new European venture capital dataset to provide new insights into the ways in which contracting and exit are interrelated. This paper provides a positive empirical analysis of the types of contracts used by venture capitalists, and a normative empirical analysis of the resulting exit process associated with different contracts and different types of entrepreneurial investments.

In the first of the two main parts of this paper, a positive analysis of functional differences in financial contracts is provided. We expand the scope of evidence on securities used in venture capital finance. While venture capitalists in the United States almost always use convertible preferred equity to finance entrepreneurial firms, venture capitalists in every other country (at least those where data are available) use a variety of forms of finance (see section II below for details). In the European venture capital data herein, we observe common equity used most frequently, but there are a wide variety of securities used in venture capital transactions. We relate the use of different securities to the type of entrepreneurial firm (e.g., stage of development, industry), board seats, specific contingencies, veto rights and other control rights. Previous research has not considered the allocation of control rights when securities other than convertible preferred equity are used.

The second of the two main parts of this paper provides a normative analysis of the performance of the different investments - in terms of the selected exit vehicle (IPO, acquisition, write-off ${ }^{3}$ ) and the IRR. This part of the analysis is based on previous research on venture capital exits (MacIntosh, 1997; Black and Gilson, 1998; Cumming and MacIntosh, 2003; 
Schweinbacher, 2001; Smith, 2001; Fleming, 2002). We extend previous research by considering, among other things, how control rights and cash flow rights among different securities affects the selection of the exit vehicle. Our data are the first European dataset that enables and investmentby-investment analysis of the selected exit vehicle, ${ }^{4}$ and the first dataset (anywhere) that enables a normative analysis of which financial structure is 'best' in venture capital finance.

This paper analyzes a hand-collected dataset involving 179 investment rounds in 132 entrepreneurial firms from 17 European venture capital funds. Coincidentally, the data are quite similar in scope to other hand-collected datasets in academic venture capital research. For example, Kaplan and Strömberg (2002) analyze 213 investment rounds in 119 portfolio companies by 14 U.S. venture capital funds. Papers by Gompers (1997) and Hellmann and Puri (2000, 2001) also use data of similar scope.

In a nutshell, the data herein indicate the following. First, different securities are not functional equivalents in venture capital contracts. That contracts other than convertible preferred equity are used is not dependent on the definition of venture capital. Second, the allocation of control rights, board seats, etc., depends on the allocation of cash flow rights through the use of different securities. Third, the selected exit vehicle and the returns to venture capital significantly depend on the allocation of cash flow and control rights in specific venture capitalist investments. The results are interpreted within the institutional context from which the data are derived, and suggest avenues for further theoretical and empirical research.

This paper is organized as follows. Section II outlines previous research. The data are described in section III. Section IV considers the determinants of contractual terms. Section V evaluates the performance of the investments under different contracts, and the likelihood of different exit outcomes. Limitations are discussed in section VI, and avenues for future theoretical and empirical research are discussed. Concluding remarks follow.

\section{Previous Research}

Our research is based on a number of earlier papers that have provided the foundation for understanding venture capital (VC) investing and exit decisions. Previous VC contracting and exit papers may be categorized into seven groups: ${ }^{5}$ 
(1) Empirical research based on U.S. data indicating the prevalent use of convertible preferred equity, staging, syndication, and various control rights, etc. (Sahlman, 1990; Lerner, 1994; Gompers, 1995, 1997; Bergmann and Hege, 1998; Gompers and Lerner, 1999; Kaplan and Strömberg, 2002);

(2) Theoretical research explaining the optimality of convertible preferred equity in venture capital based on the U.S. evidence, and the allocation of various control rights (Sahlman, 1990; Chan, et al., 1990; Berglöf, 1994; Cornelli and Yosha, 1997; Hellmann, 1998; Marx, 1998; Trester, 1998; Bergmann and Hege, 1998; Repullo and Suarez, 1998; Bascha and Walz, 2001a; Kirilenko, 2001; Schmidt, 2001; among others);

(3) Research indicating the role of U.S. tax law in biasing the selected security in the U.S. towards convertible preferred equity for U.S. entrepreneurial firms (Gilson and Schizer, 2001), but not in other jurisdictions such as Canada (Sandler, 2001);

(4) Empirical research showing the use of a variety of different securities in jurisdictions other than the United States, including Canada (Cumming, 2000), Germany (Bascha and Walz, 2001b), Finland (Parhankangas and Smith, 2000), Taiwan (Songtao, 2000), Australia (Australian Bureau of Statistics, 2000), as well as in cases of crossborder U.S. VC investments in Canadian entrepreneurial firms (Cumming, 2001), and for different types of venture capital funds (not only limited partnerships, but also corporate VCs, government VCs, etc.; Cumming, 2000); ${ }^{6}$

(5) Theoretical research on the optimality of convertible preferred equity in ensuring an efficient exit (Berglöf, 1994; Black and Gilson, 1998; Bascha and Walz, 2001; Hellmann, 2001; Smith, 2001; Schweinbacher, 2001);

(6) Empirical research examining the performance of venture-backed IPOs (Barry et al., 1990; Megginson and Weiss, 1991, Lin and Smith, 1997; Gompers and Lerner, 1999; Ljungqvist, 1999; Franzke, 2001; among others);

(7) Empirical research examining the complete choice of different venture capital exit vehicles (IPOs, acquisitions, secondary sales, buybacks, and write-offs) based on the characteristics of the entrepreneurial firms and venture capital funds (MacIntosh, 1997; Black and Gilson, 1998; Cumming and MacIntosh, 2003; Schweinbacher, 2002; Flemming, 2002), and related empirical research explaining the risk and return to venture capital (Cochrane, 2001; Smith and Smith, 2000; Manignart et al., 2000).

Previous venture capital research has not considered the allocation of control rights when securities other than convertible preferred equity are employed. In addition, previous research has not fully analyzed which types of investments and contracts typically lead to 'superior' results, in terms of the selected exit vehicle as well as the internal rate of return (IRR). The following sections provide an analysis of a new dataset that shed light on these issues, and suggest avenues for further research. 


\section{DATA}

\section{A. Description of the Data}

We consider the contracts and exits from a hand-collected sample of 17 European venture capital funds. The data comprise 179 investment rounds in 132 entrepreneurial firms (portfolio size ranges from $2-20$ entrepreneurial firms per fund). The VC funds are based in Austria (1 fund), Belgium (1), Czech Republic (1), Denmark (1), France (1), Germany (4), Italy (2), Poland (1), Switzerland (1) and The Netherlands (4). As with U.S.-based research with data of similar scope (Gompers, 1997; Kaplan and Strömberg, 2002), as well as European research (Maginart et al., 2000; Schweinbacher, 2002), the funds were selected based on their willingness to disclose very detailed confidential information about their contracts and exits. We interpret the results from this sample of funds within the institutional context.

Thirty-three actual exits and 38 expected exits are observed in the data: 10 actual IPOs; 13 actual acquisitions; 10 actual write-offs; 12 expected IPOs; 25 expected acquisitions; and 1 expected write-down of the book value of an investment (which is analogous to a partial writeoff; see Cumming and MacIntosh, 2002). The data do not appear to be driven towards the most successful or 'best' investments. The frequency of dispositions is similar to related papers on VC exits (Cumming and MacIntosh, 2003; Cochrane, 2001; Schweinbacher, 2002). That most of the investments (99 of the 132) have not been exited indicates that the data are based on recent transactions as from the date of data collection (November 2001 - February 2002). This is not surprising, given the data collection was facilitated via the use of surveys and numerous interviews with VC fund managers.

For reasons of confidentiality, the data are not presented by individual venture capital fund. Nevertheless, the results are not attributable to the presence of any fund, group of funds, and/or type of fund in the data. For example, most every fund in the sample uses a variety of forms of finance (there were two exceptions: 1 fund used mostly convertible preferred equity, and one fund used mostly common equity). As well, most of the regression analyses below incorporate fixed effect VC fund dummy variables. Note that an alternative (and nearly equivalent) specification for the regressions in each of the tables is with location dummy variables (i.e., institutional and legal differences across the countries in the data). These regressions yielded nearly identical results (and are available upon request). In addition, note that 
the presence of buyout investments in the data does not materially change any of the main results (the tables without buyouts are available upon request).

The data on the types of contracts selected are summarized in Tables 1a - 1f. The data are presented by entrepreneurial firm (with the one exception in Table 1a, where the number of financing rounds are reported in column 4). The types of securities used are broken down into four main categories: common equity, convertible preferred equity, mixes of common and preferred equity, and mixes of debt with common equity. As well, the (rare) cases in which syndicated VCs used different financing instruments are reported (see Schindele, 2002, for a theoretical analysis). Consistent with research from outside the U.S. - see Bascha and Walz (2001), Cumming (2000), Smith and Parhankangas (2001), Songtao (2001), etc. - common equity is used most frequently by venture capitalists, but a variety of forms of finance are observed.

\section{[Tables 1a - 1f About Here]}

Table 1a summarizes the data by the number of cases in which the respondent VC fund was the lead investor, the number of syndicated investments and financing rounds, and the number of $\mathrm{VC}$ board seats. We do not observe many financing rounds, nor do we observe significant variation among the financing rounds in this dataset (see Gompers, 1997, and Kaplan and Strömberg, 2002, for greater variation across financing rounds in the U.S.). All the data and regressions in this paper are therefore presented by the 132 entrepreneurial firms, and not by the 179 investment rounds.

Table $1 \mathrm{~b}$ indicates the stages of development of the entrepreneurial firms in the sample, as well as the industries. The investment stages are commonly used by the European Venture Capital Association (www.evca.com), as well as in the United States (www.vfinance.com, www.ventureeconomics.com, www.v1.com), Canada (www.canadavc.com) and other countries.

Table 1c relates the selected forms of finance to exits (both actual and expected). The relations between these variables are considered in more detail in the subsequent sections.

Tables 1d - 1f report the data relating the securities to the specific contractual contingencies (see Appendix A for examples), veto rights and various control rights (see Appendix B for examples). Categories of particular contractual contingencies are based on those 
reported by Kaplan and Strömberg (2002) in the U.S., as similar contingencies are found in the European VC data: financial, non-financial, certain actions, and sale of equity (see Appendix A). The European data distinguish between contingencies designed to for motivate the entrepreneur from contingencies designed to motivate the venture capitalist or syndicated investors.

Table $2 \mathrm{a}$ indicates the frequency of exits by firm characteristics, and Table $2 \mathrm{~b}$ indicates the frequency of exits by control rights. Average IRRs are slightly higher for actual acquisitions than actual IPOs (and the reverse is true for expected exits), but these differences in means are not statistically significant (t-statistics for differences in average IRRs for actual and expected IPOs and acquisitions were less than 1.0).

[Tables $2 \mathrm{a}$ and $2 \mathrm{~b}$ About Here]

An interesting feature of the data is the presence of a greater number of reported expected acquisitions. Many VC fund managers did not expect the IPO market to be 'strong enough' over the coming months, up to year 2004. 'Preplanned' was given as the primary reason for exit in most cases (46). There were also 4 unsolicited offers, 12 exits for reasons of market conditions, 7 internal conflicts giving rise to write-offs, 2 exits for fundraising reasons, and 1 exit inspired by fund termination. The respondent VC controlled the exit in most (52) cases. Conflicts regarding the exit process were rare: 8 surrounded the timing of the exit, and 1 was regarding valuation. It is noteworthy, however, that 5 of the 10 actual IPOs involved a conflict about the timing of the exit, and 1 actual IPO involved a conflict about the valuation.

\section{B. Are Different Securities in VC Contracts Functionally Equivalent? Univariate Tests}

Theoretical research has offered many explanations for the financial structure of U.S. VC-backed entrepreneurial firms: U.S. VCs finance U.S. entrepreneurial firms with the use of convertible preferred equity. As explained by Gilson and Schizer (2002), there are at least four limiting aspects of this theoretical research. First, the formal attributes of convertible preferred equity, such as liquidation and dividend preference, are insubstantial in practice because failed entrepreneurial ventures typically do not have assets for distribution to VCs. ${ }^{7}$ Second, the theories cannot explain the use of convertible preferred equity in particular, rather than financial contracts that are functionally equivalent. Third, Gilson and Schizer explain the fact that some theories are unlikely to operate as modeled, such as the allocation of control between 
entrepreneurs and venture capitalists in exit. Fourth, existing models cannot explain the fact that VCs in different countries use a variety of forms of finance. ${ }^{8}$ Even sophisticated U.S. VCs use different forms of finance when they invest in entrepreneurial firms located in different countries, such as Canada (Cumming, 2002). Gilson and Schizer (2002) explain that the prevalent use of convertible preferred equity for U.S. venture backed firms is primarily related to the fact that U.S. tax practice enables more favorable entrepreneurial incentive compensation.

If U.S. tax law colors the selected form of finance for venture-backed firms in the U.S., then it is important to test financial contracting theories using data from entrepreneurial firms in countries other than the U.S. for at least three reasons. First, with U.S. data, it is not directly possible to ascertain whether convertible preferred equity is optimal in the absence of a tax bias favoring the use of such securities. Second, it is not possible to test the relationship between different forms of finance and various control rights if tax laws exogenously determine the selected security. Third, it is not possible to ascertain whether the use of different securities is related to differences in exit strategies.

Table 3a summarizes the data by providing statistical tests for the significance of the correlation coefficients between the securities and various other variables (actually, the reported significance test is the Chi-squared for the cross-tabulations; see Greene, 1998, p.245).

[Table 3a About Here]

Importantly, Table 3a indicates that the use of specific contingencies is complementary to the financing instrument. ${ }^{9}$ Contingencies are statistically more likely to be used for both the VC and the entrepreneur when convertible preferred equity is the selected financing instrument. When common equity is selected, contingencies are statistically less likely to be employed. When mixes of debt and common equity are used, or mixes of preferred equity and common equity are used, there is no statistical relationship to the use of specific contingencies.

The use of veto rights is statistically negatively related to the use of common equity, and statistically positively related to the use of convertible preferred equity. Veto rights are also statistically positively related to mixes of preferred and common, but statistically independent of debt and common equity. 
Similar to the relation between veto rights and security choice is the relation between other control rights and security choice. VCs typically have fewer control rights with common equity, and more control rights when mixes of preferred and common are used. When convertible preferred equity is used, VCs are less likely to have the right to replace the CEO and have redemption rights, but more likely to have information rights and the right of first refusal in sale of the firm as well as protection rights against new issues. Most of the specific control rights are independent of the security choice when mixes of debt and common equity are used.

VCs obtain statistically smaller ownership percentages when convertible preferred equity is the selected financing instrument, and statistically greater ownership percentages when mixes of preferred and common are used. The univariate tests reveal no statistical relation between ownership percentage and the use of common equity or mixes of debt and common equity.

VCs are statistically more likely to obtain a majority of the board seats when mixes of debt and common equity are used. Obtaining a majority of the board is unrelated to the other types of securities in the univariate tests.

Convertible preferred equity is more likely to be used with seed and early stage investments, and with firms in the Internet/communications sectors. Common equity is used more often for expansion stage investments and firms in the medical/biotech industries.

In sum, different securities are functionally distinct. Specific contractual terms are not used so that different securities may mimic one another. That is, the specific terms appear to be complements with the security choice. Why? Many VCs indicated that the particular deals with simple payoff structures (common equity) are typically associated with few contractual provisions (such as veto rights and other specific control rights) because the important distinguishing aspect of the deal is in its simplicity. Lead investors often 'shy away' from complicated structures that do not facilitate room for negotiation with potentially new syndicated outside investors (see Lerner, 1994, on the relation between lead and follow-on investors). Moreover, entrepreneurs are often dissuaded by excessively complicated financing arrangements (see Black and Gilson, 1998, on 'implicit' contracts in venture capital, and subsection III.C below). Low IRRs have in some cases been attributed to excessively complicated deal structures. 


\section{Are Different Contracts Related to Different Exit Vehicles? Univariate Tests}

Similar to Table 3a, Table $3 \mathrm{~b}$ summarizes the data by providing statistical tests for the significance of the correlation coefficients between the different exit vehicles and various other variables (as mentioned above, the reported significance test is the Chi-squared for the crosstabulations; see Greene, 1998, p.245).

[Table 3b About Here]

Table $3 \mathrm{~b}$ indicates two main findings. First, the use of common equity is more often related to IPO exits, and less often to acquisitions. Second, the use of specific control rights and veto rights (which are related to convertibles; see Table 3a) are more often associated with acquisition exits, not IPOs. This supports Black and Gilson's (1998) implicit contracting theory. Black and Gilson argue that there is often an implicit contract between VCs and entrepreneurs to transfer control back to the entrepreneur upon an IPO exit (which is in the interest of the entrepreneur). IPOs are observed with greater frequency when there are not many explicit covenants in the form of veto rights and control rights. In contrast, when many explicit covenants are used, acquisitions are the more common outcome.

In the subsections below, we consider in a multivariate framework the allocation of various control rights and choice of security (section IV). We also consider the likelihood of different exits based on the type of firm and type of contract in a multivariate setting (section V).

\section{WHAT DETERMINES THE SECURITY, VC OWNERSHIP \%, BOARD SEATS, VETO \& CONTROL Rights? Multivariate ANALYSIS}

\section{A. Sequence of Decisions}

Interviews with many European venture capital fund managers indicated the following typical sequence of events in designing venture capital contracts. First, the required rate of return is determined to make the investment worthwhile (depending on firm characteristics technology, development stage, etc.). This involves selecting a security that will provide the payoff to fit with the risk and required return. It is noteworthy that VC funds typically do not care about the downside. Similarly, Gilson and Schizer (2002) note that VCs rarely care about bankruptcy proceedings because the few assets remaining in a bankrupt $\mathrm{VC}$ investment are 
typically absent of any meaningful value. Second, ownership percentages and board seats are allocated, subject to the selected security. Third, over a negotiation period (typically a few months, and longer in poor economic conditions), specific control rights are allocated depending on the ownership structure and security to make sure both parties are 'happy' and the deal proceeds forward.

The multivariate regression equations below are based on this sequence of decisions. An issue that arises is in the joint determination of some of the variables in the various tables (but the main results are robust to alternative specifications; alternatives are available upon request). Table 4 provides correlation coefficients across many of the variables used in the various regressions. There are only a few significant correlation coefficients. Nevertheless, the results are not biased by collinearity between the explanatory variables, or by problems of endogeneity, etc. Given the large number of tables presented, additional tables with supporting robustness checks are not provided (but are available upon request). While most regressions employ fixed effects for different VC funds, the results are fairly robust to the simpler alternative specification of using a constant without fixed effects. In all regressions, White's HCCME is used.

[Table 4 About Here]

\section{B. What Determines the Selected Security?}

Cumming (2000) (with Canadian VC data) and Bascha and Walz (2001) (with German $\mathrm{VC}$ data) have considered determinants of the form of finance based on the characteristics of the entrepreneurial firm receiving financing. Our analysis is similar. Table 5 provides binomial logit (Table 5a) and multinomial logit (Theil, 1969) (Table 5b) regressions of the determinants of the selected security based on the development stage of the entrepreneurial firm (late, turnaround and buyout stages are suppressed to avoid collinerity problems), the amount invested (book value), whether the $\mathrm{VC}$ was the lead investor, the number of syndicated partners, whether there was a preplanned IPO or acquisition, and the industry in which the entrepreneurial firm operates (medical/biotech, electronics/computer, and communications/Internet ${ }^{10}$ ). 
The binomial and multinomial logit specifications yield quite robust results. The coefficients for the seed, early and expansion dummy variables indicate that convertible preferred equity securities are most likely. This is consistent with most academic venture capital research indicating convertible preferred equity is the optimal security (see, e.g., Sahlman, 1990; Cornelli and Yosha, 1997; Gompers, 1997; Kaplan and Strömberg, 2002).

The binomial logit estimates indicate (at the $1 \%$ level of significance) that lead investors are less likely to use convertible preferred equity. Some European lead investors indicated they often do not use complicated financing structures in order to facilitate negotiation with potentially new syndicated outside investors.

There are other characteristics of the entrepreneurial firm, as well as characteristics of the investor(s) that may affect the selected form of finance. However, in the multinomial logit setting, the variables other than the stage of development variables are generally insignificant (see Cumming, 2000, and Bascha and Walz, 2001, for contrasting evidence).

The predictive power of the regression models is indicated at the bottom of the tables. The match between actual and predicted outcomes is fairly strong, but not perfect. Other lessvisible factors may play a role (e.g., a behavioral finance type variable such as 'a need for simplicity', and other entrepreneur firm variables could be used, based on interviews with VCs).

\section{What Determines VC Ownership Percentage and the Percentage of VC Board Seats?}

Table 6 presents regressions for the determinants of VC ownership percentage. ${ }^{11}$ Three binomial logit regressions are provided for the following left-hand side variable: (model 1) respondent VC ownership $>50 \%$, (model 2) respondent + syndicated VC ownership $>50 \%$, and (model 3) contingent VC equity ownership (specific clauses aside from the security itself giving the investor more equity in cases of poor performance of the entrepreneurial firm). As well, two OLS regressions are provided for (model 4) the respondent VC's ownership percentage and (model 5) the sum of the respondent VC and the syndicated VCs' ownership percentage. ${ }^{12}$

[Table 6 About Here] 
The regression results indicate contingent VC equity ownership (model 3) is significantly less likely for seed and early stage firms. Firms in these early development stages typically do not have positive cash flows; therefore, contracts allocating equity contingent on performance are not as feasible. There is evidence that seed investments give the $\mathrm{VC}$ a large equity $\%$ (models 1 and 5), possibly to compensate the investor for the risks associated with such early stage investments. In contrast, expansion stage investments are more typically associated with lower a VC ownership \% (models 1, 2, 4 and 5).

There is evidence that larger VC investments increase VC ownership \%, as would be expected (see, e.g., Noe and Rebello, 1996, Propositions 3 and 4), but this result is only significant in model 2. Similarly, the greater the number of syndicated investors, the smaller the equity ownership of each VC (model 1 and 4).

Contracts with contingent equity allocations are complementary to the security: they are used with convertible preferred equity (model 3). Larger VC equity ownership \% is associated with contracts involving mixes of debt and common equity (models 4 and 5).

VCs take a majority ownership \% when they are preplanning an acquisition exit (model 1). This is consistent with Black and Gilson (1998). Black and Gilson argue that entrepreneurs prefer IPO exits insofar as the entrepreneurial team regains control over the firm upon an IPO exit (acquisitions transfer control to the acquiror).

Industry dummy variables indicate tech entrepreneurial firms - particularly those in the Internet/communications industries - are less likely to involve majority VC equity ownership (models 1 and 2).

Similar to Table 6, Table 7 presents 5 regressions for the determinants of $\mathrm{VC}$ board seats. The results are quite consistent with those in Table 6 .

\section{[Table 7 About Here]}

VCs typically do not take a majority of the board for seed, early and expansion stage investments. However, the greater the $\mathrm{VC}$ ownership \%, the $\mathrm{VC}$ will take a larger \% of the board seats, and will more often control the board. 
As with contingent equity ownership \%, contracts involving contingent board seats in cases of poor performance are used for expansion stage investments, but not seed and early stage investments. Again, as with contingent equity ownership \%, contingent board seats complement the security: convertible preferred equity, not common equity or mixes of debt and common equity. It is also noteworthy that VCs typically take fewer board seats when convertible preferred equity is used.

The evidence indicates that for investments in which exit is preplanned (both preplanned IPOs and preplanned acquisitions), VCs take relatively fewer board seats. While this may be somewhat surprising, as discussed below, VCs can control the exit decision in other ways (i.e., independently allocate control over exit).

Investments in high-tech industries also appear to typically involve fewer VC board seats. We may have expected greater VC board representation among firms in industries where assets are typically intangible and more monitoring is required. Nevertheless, contingent VC board seats are more likely for the high-tech firms (at least those in the biotech/medical industries).

\section{What Determines the use of Contractual Contingencies?}

Table 8 presents logit regressions for the determinants of contractual contingencies that are designed to provide effort incentives to the entrepreneur and/or the venture capitalist (specific contractual terms not directly part of the financing instrument; see Appendix A).

[Table 8 About Here]

Interestingly, $\mathrm{VCs}$ are less likely to use self-motivating contractual terms when they act in the capacity of lead investor. Based on conversations with venture capitalists, the reason is simple: it is more difficult to develop syndication relationships with outside investors when such clauses are part of the lead investor's contract with the entrepreneur.

When VCs take a majority stake in the firm, incentive clauses are used significantly less frequently. Similarly, there is some evidence that incentive clauses for the entrepreneur are less 
likely (specifically clauses pertaining to non-financial performance and certain actions) when the $\mathrm{VC}$ provides more capital.

Consistent with contingent board seat allocation (see subsection IV.C.), the use of specific contingent incentive clauses for both venture capitalists and entrepreneurs appears to be complementary with the particular security: they are used more frequently with convertible preferred equity, and less frequently with common equity. As discussed in section III, this is further evidence that different securities are not functionally equivalent.

Contingent clauses for entrepreneurs are used more frequently in medical/biotech industries. Interviews with VC fund managers revealed that entrepreneurs in the industries are necessarily provided with specific incentives to obtain patents, and achieve other milestones.

Finally, the evidence indicates preplanned exits involve contingencies for both the entrepreneur and the venture capitalist so that both have incentives to ensure that exit objectives are fulfilled.

\section{E. When Do VCs Use Veto Rights?}

Table 9 presents logit estimates for the determinants of veto rights over asset sales, asset purchases, changes in control and other decisions.

\section{[Table 9 About Here]}

Veto rights are most often used in the seed stage of development, and are less common in the early and expansion stages. This reflects the difficulty that venture capitalists face in terms of widely recognized agency problems, such as risk shifting, etc., among very young firms where the direction of the firm is highly variable. Lead investors are also more likely to use veto rights.

As with the evidence in the previous subsections, the use of veto rights is complementary to the security choice. Veto rights are more common with convertible securities. Therefore, for example, while convertibles mitigate risk-shifting agency problems (Green, 1984), they are used in conjunction with veto rights. Veto rights are less likely to be used with other securities. 
Similarly, when the VC has board control, veto rights are more likely for decisions over asset sales. This further supports the view that contractual terms are complementary, and not substitutes.

In this sample, veto rights are more frequently used in biotech/medical and computer/electronics industries.

\section{F. How Are Control Rights Allocated when Capital Structure is Flexible?}

Logit regressions for the determinants of specific control rights (see Appendix B for examples) are presented in Table 10.

[Table 10 About Here]

Accounting for other firm characteristics (discussed below), the early development stage firms (seed, early and expansion stages) are statistically less likely to be financed under most of these control rights.

Lead investors typically require most of the control rights (with the exception of automatic conversion upon IPO).

VC funds that hold a majority of the board seats also hold a specific contractual right to replace the CEO. Common equity contracts typically involve few specific control rights. Both of these results provide further support for the view that VC contractual terms are complementary.

Convertible preferred equity contracts typically also involve the right of first refusal in sale, as well as demand registration rights and piggyback registration rights. Consistent with Berglöf (1994), this indicates that convertible preferred equity mitigates trilateral bargaining problems associated with the sale of the firm, ${ }^{13}$ and the particular associated contractual terms to mitigate this trilateral bargaining problem are complements with the selected security. Convertible preferred equity is not statistically related to the use of other control rights.

Control rights are more common among medical/biotech and computer/electronic firms than Internet/communications firms in the sample. 
Interestingly, control rights are used much more frequently when there is a preplanned acquisition as opposed to a preplanned IPO. Consistent with Black and Gilson (1998), entrepreneurs typically prefer IPO exits so that they may regain control over the firm upon VC exit. When acquisitions are planned, VCs typically put in place a greater number of contractual mechanisms to effect an acquisition exit.

The following section considers the normative implications of financing different entrepreneurial firms with different contracts.

\section{How Well Do Investments Perform Under Alternative Contracts? MUlTiVARIATE ANALYSIS}

In the preceding section we presented statistics and regressions for determinants of contract choice. In this section our attention is focused on the implications associated with the use of different contractual terms. Two questions arise. First, how is the exit vehicle affected by the specific contractual terms, controlling for other firm characteristics? Second, do different contracts affect IRRs given the other firm characteristics?

We caution that only 33 of the 132 portfolio companies in the sample have been exited. The actual exits span the period from 1997 - 2001. We control for exits for reasons of 'market conditions'. There are also 38 expected exits, up to year 2004. While many statistically significant results are obtainable from the sample, the data also suggest avenues for further normative research.

\section{A. Choice of Exit Vehicle}

Table 11 presents regressions for the determinants of exit choice (both actual and expected $\left.{ }^{14}\right)$. Fixed effect dummies are used to control for differences between actual and expected exits in some of the specifications to illustrate robustness. Degrees of freedom do not permit inclusion of every specific contractual clause in the regressions; therefore, variables that aggregate the number of contingencies (subsection IV.D; Appendix A), veto rights (subsection IV.E), and control rights (subsection IV.F; Appendix B) are employed.

[Table 11 About Here] 
The evidence indicates that IPOs are more likely when common equity is used, and when there are a greater number of incentive contingencies in contracts. ${ }^{15}$ There has been theoretical research connecting convertible securities to exit strategies (e.g., Berglöf, 1994; Bascha and Walz, 2001; Hellmann, 2001). Because VCs outside the U.S. most often use forms of finance other than convertible preferred equity (or functional equivalents), future theoretical research relating alternative forms of finance and specific contractual clauses to the exit strategy would be fruitful. Because the evidence herein is suggestive that specific control and veto rights with convertibles securities are less frequently associated with IPOs, it is supportive of Black and Gilson's (1998) implicit contracting theory of control transfer back to entrepreneurs upon IPO. $\mathrm{VC}$ control rights are used to effect acquisitions.

Market conditions also significantly increase the likelihood of an IPO exit. IPOs are also more likely when there are a greater number of syndicated VC investors. This evidence supports related research. Gompers and Lerner (1999) show U.S. VCs are particularly skilled at timing the IPO market, and VC syndicates facilitate certification of entrepreneurial firm quality upon IPO (and possibly enable the VCs to collude and overstate entrepreneurial firm value upon exit).

Table 11 indicates that write-offs occur after the shortest investment duration: bad information is revealed quickly (this is consistent with Cumming and MacIntosh, 2002). The duration of investment does not impact upon the decision of an IPO versus an acquisition. Firms with the lowest market/book ratios obviously are written off, but there is no evidence that market/book differences affect the likelihood of an IPO or acquisition in this dataset. ${ }^{16}$

When entrepreneurs control the exit decision, IPOs are more likely, and write-offs are less likely. Again, this is consistent with Black and Gilson's view that entrepreneurs prefer IPOs to regain control over the firm. It is also consistent with Petty et al.'s (1999) case studies on entrepreneur's attachment to their firms - their reluctance to sell the firm in an acquisition, and their reluctance to write-off their companies.

\section{B. Determinants of IRR}

Cochrane (2001, page 2) recognizes some distinguishing features of venture capital investing: poor liquidity, poor diversification, and information and monitoring. Gompers and 
Lerner (1999) have extensively analyzed these aspects of venture capital investing. Cochrane, however, also states (page 2): "On the other hand, venture capital is a competitive business with free entry... Many venture capital firms are large enough to effectively diversify their portfolios. The special relationship, information and monitoring stories suggest a restricted supply of venture capital may be overblown. Private equity may be just like public equity." Cochrane therefore bases the measure of risk and return of venture capital on the Capital Asset Pricing Model (CAPM). The distinguishing feature of Cochrane's paper is the use of selection effects associated with the different exit vehicles. ${ }^{17}$

A useful lecture prepared by Giorgio Szegö (2001) provides some guidance as to the applicability of the CAPM to the context of venture capital. Szegö (at page 3) stresses that "[i]f the joint distribution function of the $\mathrm{n}$ returns of a portfolio is elliptical, then and only then the Markowitz-Sharpe mean-variance- $\beta$ can be used." It is noteworthy that t-distributions are elliptical, and normal distributions are spherical (a special case of an ellipsoid), but it is highly unlikely that the returns to venture capital are elliptical. The returns to venture capital are multimodal (MacIntosh, 1997; 1999; Cumming and MacIntosh, 2002, 2003; Smith and Smith, 2000; Cochrane, 2001): there is a high percentage (typically around $25 \%$ of all investments) of write-offs (-100\% return), many investments generate a "good" annualized return of between 25 $100 \%$, and the lions-share of venture capital profits comes from a few very successful "homerun" investments with returns of more than $500 \%$.

We therefore do not use a market model to explain returns. Most venture capital funds are not well diversified (the funds in this sample had between 2 and 20 investments in their portfolios); see also Kanniainen and Keuschnigg (2001a,b). The view taken here is that returns primarily depend on the characteristics of the investee and the nature of the contracts employed. ${ }^{18}$

Table 12 presents multivariate regressions for the determinants of IRRs for both the actual and expected exits together, as well as the actual exits separately. (IRRs for expected exits were calculated on the basis of market values of the investees as at September 2001.) While a large number of variables are included, the results are quite robust to the inclusion/exclusion of other variables (details are available upon request). The results with a fairly complete set of variables under 4 alternative specifications are discussed below. It is noteworthy that the predictive power of the model is strong: for the actual exits the adjusted $\mathrm{R}^{2}$ is greater than $85 \%$. 
[Table 12 About Here]

Table 12 indicates IPOs and acquisitions (naturally) give rise to higher returns (a dummy for write-offs was suppressed to avoid collinearity). The difference between the IPO and acquisition coefficient values was not statistically significant.

Higher VC ownership percentages also increased the IRRs to the VCs in the subsample of actual exits (Table 12), and medical/biotech and Internet/communications industries had significantly higher IRRs in the sample.

The variable for market conditions in Table 12 is negative and significant, because market conditions sometimes gave rise to write-offs in this sample. Earlier stage investments also yielded lower IRRs, due to the write-offs in the sample from those investment stages.

The use of convertible preferred equity, and mixes of common equity and debt give rise to lower IRRs in this sample. Common equity, on the other hand, does not lower IRRs. The results are suggestive that simple financial structures 'work well'. Further empirical research is warranted.

\section{LIMITATIONS AND FUTURE RESEARCH}

The degrees of freedom do not permit inclusion of every specific contractual clause in the regressions in Table 11 and 12. Therefore, variables that aggregate the number of contingencies (subsection IV.D), veto rights (subsection IV.E), and control rights (subsection IV.F) are employed. IRRs were higher when VCs had a greater number of veto rights, but lower when contracts contained a greater number of control rights. Again, these results are suggestive of the value of particular clauses in VC contracts, but the limitations of the data (particularly the aggregation of clauses of similar type due to the limitation in degrees of freedom) give rise to a need for further research. As well, while we have used dummies for investor effects (or equivalently, country effects), further research on the impact of laws and institutions on contract structure and exit choice would be worthwhile (see also Black and Gilson, 1998).

It is noteworthy that the VC funds in this dataset typically do not serve on boards of directors of entrepreneurial firms after 1 year of the exit date. (There were 2 exceptions for the 
IPO exits - one actual IPO and one expected IPO - and in the expected exit, it was the syndicated VC that was expected to remain on the board). Similarly, VC funds maintained an ownership interest in the entrepreneurial firm for more than one year after exit in only three exits (two of these cases overlapped with the two cases of $\mathrm{VC}$ board representation for more than 1 year after exit).

Three of the acquisition exits in this sample involved some exchange of shares (instead of complete payment in cash). Share consideration in acquisition exits is analogous to a partial acquisition (Cumming and MacIntosh, 2002). The three cases were not materially different from the other acquisitions in this sample. Further research with additional European data would be worthwhile.

Finally, further research on the long-term performance of European VC IPO and acquisition exits depending on the role of the VC fund(s) pre- and post-exit, and on the nature of financial contracts between entrepreneurs and VCs and would be fruitful (see Gompers and Lerner, 1999, 2001, 2002, for related U.S.-based VC research).

\section{CONCLUSION}

The empirical evidence provided in this paper adds to the understanding of venture capital finance in two important respects. First, venture capital contracts for different types of entrepreneurial firms are functionally distinct. They can involve different securities (common equity, convertible preferred equity, mixes of debt and common, and mixes of preferred and common). They can also involve other specific contractual provisions pertaining to control rights, veto rights, board seats, etc. Each of these contractual provisions tends to be complementary, not substitutes. As such, different contracts are not functional equivalents.

Second, the use of different contracts - both the securities and specific contractual terms pertaining to cash flow and control rights - are important insofar as they play a role in determining the eventual exit vehicle selected, as well as the VC's IRR. Venture capital is nondiversified, value-added, active investing. Returns are a function of the types of entrepreneurial firms financed and the governance mechanisms used to oversee these firms. 
The empirical evidence herein provides insight along these two dimensions. We hope that this evidence inspires further theoretical and empirical research so that we may better understand the financing process, and better evaluate the normative implications associated with different contracts and investments in different types of entrepreneurial firms.

\section{Appendix A: Examples of Various Contractual Contingencies ${ }^{19}$}

Financial contingencies: Employee shares vest if revenue goals attained; VC can only vote for all owned shares if realized EBIT below threshold value, in which case VC always gets voting control; VC dividend on preferred shares, payable in common stock, is suspended depending on actual revenues and operating profits versus expected revenue and profit goals; exercise price on warrants is fraction of net worth: (e.g.) $50 \%$ of net worth/share for first three years, then $100 \%$ of net worth/share; VC warrants expire if revenue goal attained; Committed round of financing contingent on no material deviation from business plan.

Non-financial contingencies: Committed round of financing contingent on no material deviation from non-financial aspects of business plan; Employee shares vest when company secures threshold number of customers who have purchased the product and give positive feedback; Employee shares vest when release of new major version of the product which incorporates significant new functionality; Founder shares vest contingent on governmental approval of new drug; Founder shares vest contingent on new corporate partnership found; Founder shares vest contingent on approved patents; Founder loses voting right for shares if terminated for cause (e.g., illegal activities, etc.); Committed funding paid out when new clinical tests completed; Committed funding paid out when new strategic partnership completed.

Certain actions taken contingencies: Committed funding paid out subject to new business plan for entering new markets completed and approved by board; Vesting of shares contingent on hiring new key executives; Committed funding paid out subject to hiring new key executives or CEO; Committed funding paid out subject to developing new facilities.

Sale of equity contingencies: Founder ownership increasing non-linear function of share price obtained in sale or IPO; Founder vesting accelerates upon sale or IPO of certain minimum value; Cumulative dividend (in stock or cash) suspended upon sale or IPO of certain minimum value; Conversion price of $\mathrm{VC}$ convertibles higher if company completes sale of new equity where 
proceeds exceed minimum amount; $\mathrm{VC}$ warrants expire if company manages to raise alternative funds where proceeds and price of equity exceeds threshold; VC warrants expire upon IPO of minimum value; Committed funding paid out when new vendor financing agreements secured; Committed funding paid out when new construction loans secured; VC dividend on preferred shares, payable in common stock, is suspended if company manages to raise certain amount of new funding above minimum price per share.

\section{Appendix B: Examples of Contractual Clauses Pertaining to Control Rights ${ }^{20}$}

Right of First Refusal: The Investors shall have the right in the event the Company proposes to offer equity securities to any person (with exceptions). This right typically terminates upon IPO.

Co-sale Agreement: The entrepreneurial managers may not sell, transfer, or exchange their stock unless each investor has an opportunity to participate in the sale on a pro rata basis. The right of co-sale shall not apply to and shall not terminate upon the Company's initial public offering.

Antidilution Provisions: The conversion price of convertible securities are subject to a weighted average adjustment to reduce dilution in the event that the Company issues additional equity securities (other than employee, director, and consultant shares approved by the Board of Directors) at a purchase price less than the applicable conversion price.

Protection Rights Against New Issues: Consent of the investors shall be required for any investee action that changes the shareholder rights and privileges of the investors.

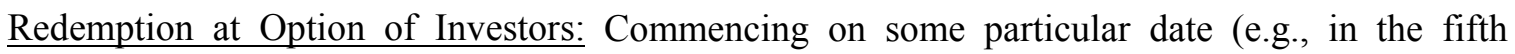
anniversary of the Closing), at the election of the investors, the Company shall redeem their outstanding shares. Such redemption shall be at the Original Purchase Price plus any unpaid cumulative dividends.

Information Rights in Operating Plans and Financials: The Company shall deliver to the Investor audited annual and unaudited quarterly financial statements. Each investor shall also be entitled to standard inspection and visitation rights. These provisions shall terminate upon a registered public offering of the Company's Common Stock. 
IPO Demand Registration Rights: The investors may force the company to file a Registration Statement for the Registrable Securities. The Company will use its best efforts to cause such shares to be registered; provided, however, that the Company shall not be obligated to effect any such registration prior to a certain specified date.

Piggyback Registration Rights: The Investors shall be entitled to "piggyback" registration rights on all registrations of the Company or on any demand registrations of any other investor subject to the right, however, of the Company and its underwriters to reduce the number of shares proposed to be registered pro rata in view of market conditions. 


\section{REFERENCES}

Aghion, P., and P. Bolton, “An Incomplete Contracts Approach to Financial Contracting," Review of Economic Studies 59 (1992), 473-94.

Australian Bureau of Statistics, Survey of Venture Capital Financial Information (2001).

Barry, C.B., C.J. Muscarella, J.W. Peavy III, and M.R. Vetsuypens, "The Role of Venture Capitalists in the Creation of Public Companies: Evidence from the Going Public Process," Journal of Financial Economics 27 (1990), 447-71.

Bascha, A., and U. Walz, "Convertible Securities and Optimal Exit Decisions in Venture Capital Finance," Journal of Corporate Finance 7 (2001a), 285-306.

Bascha, A., and U. Walz, "Financing Practices in the German Venture Capital Industry: An Empirical Assessment," Working Paper, University of Tünbingen (2001b).

Berglöf, E., "A Control Theory of Venture Capital Finance," Journal of Law, Economics, and Organization 10 (1994), 247-67.

Bergmann, D., and U. Hege, "Venture Capital Financing, Moral Hazard, and Learning," Journal of Banking \& Finance 22 (1998), 703-35.

Black, B.S., and R.J. Gilson, "Venture Capital and the Structure of Capital Markets: Banks versus Stock Markets," Journal of Financial Economics 47 (1998), 243-77.

Cestone, G., "Venture Capital Meets Contract Theory: Risky Claims or Formal Control?" Working Paper, University of Toulouse and Institut d'Analisi Economica, Barcelona (2000).

Chan, Y-S., D.R. Siegel, and A.V. Thakor, "Learning, Corporate Control and Performance Requirements in Venture Capital Contracts," International Economic Review 31 (1990), $365-82$.

Chemmanur, T., and Z. Chen, "Angels, Venture Capitalists and Entrepreneurs. A Dynamic Model of Private Equity Financing," Working Paper. Boston College and University of Pennsylvania. (2002).

Cochrane, J., "The Risk and Return to Venture Capital," Working Paper. University of Chicago Graduate School of Business (2001).

Cornelli, F., and O. Yosha, "Stage Financing and the Role of Convertible Debt," London Business School Working Paper No. 253-1997.

Cumming, D.J., 2000. "The Convertible Preferred Equity Puzzle in Canadian Venture Capital Finance," Working Paper. University of Alberta School of Business (2000).

Cumming, D.J., 2001. "United States Venture Capital Financial Contracting: Foreign Securities," Working paper. University of Alberta School of Business (2001). 
Cumming, D.J., and J.G. MacIntosh, "A Cross-Country Comparison of Full and Partial Venture Capital Exits," Journal of Banking and Finance, forthcoming (2002).

Cumming, D.J., and J.G. MacIntosh, "Venture Capital Exits in Canada and the United States," University of Toronto Law Journal, forthcoming (2003).

Fleming, G., "Exit Strategies in Australian Venture Capital: How Important are IPOs?" Working Paper. Australian National University (2002).

Franzke, S.A., "Underpricing of Venture-Backed and Non-Venture-Backed IPOs: Germany's Neuer Market," Working Paper, Center for Financial Studies, University of Frankfurt (2001).

Garmaise, M., "Informed Investors and the Financing of Entrepreneurial Projects," Working Paper, University of Chicago Graduate School of Business (2000).

Gilson, R.J. and D.M. Schizer, "Understanding Venture Capital Structure: A Tax Explanation for Convertible Preferred Stock Financing," Working Paper, Columbia Law School (2002).

Gompers, P.A., "Optimal Investment, Monitoring, and the Staging of Venture Capital," Journal of Finance 50 (1995), 1461-89.

Gompers, P.A., "Ownership and Control in Entrepreneurial Firms: An Examination of Convertible Securities in Venture Capital Investments," Working paper. Harvard University (1997).

Gompers, P.A., and J. Lerner, "The Use of Covenants: An Empirical Analysis of Venture Partnership Agreements," Journal of Law and Economics 39 (1996), 463-98.

Gompers, P.A., and J. Lerner, "What drives venture capital fundraising?" Brookings Papers on Economic Activity: Microeconomics (1998), pp.149-204.

Gompers, P.A., and J. Lerner, The Venture Capital Cycle, Cambridge: MIT Press (1999).

Gompers, P.A. and J. Lerner, The Money of Invention: How Venture Capital Creates New Wealth, Cambridge: Harvard Business School Press (2001).

Gompers, P.A., and J. Lerner, "Money Chasing Deals? The Impact of Fund Inflows on the Valuation of Private Equity Investments," Journal of Financial Economics 55 (2002), 281325 .

Green, R., "Investment Incentives, Debt, and Warrants," Journal of Financial Economics 13 (1984), 115-36.

Greene, W., Limdep Econometrics User Manual. Econometric Software Inc. (1998).

Hellmann, T., 1998. The allocation of control rights in venture capital contracts. Rand Journal of Economics 29 (1998), 57-76.

Hellmann, T., "IPOs, Acquisitions and the Use of Convertible Securities in Venture Capital," Working paper. Stanford University (2000). 
Hellmann, T., and M. Puri, “The Interaction Between Product Market and Financing Strategy: The Role of Venture Capital," Review of Financial Studies 13 (2000), 959-984.

Hellmann, T., and M. Puri, "Venture Capital and the Professionalization of Start-up Firms: Empirical Evidence," Journal of Finance 57 (2002), 169-197.

Jeng, L.A., and Wells, P.C., "The Determinants of Venture Capital Fundraising: Evidence Across Countries," Journal of Corporate Finance 6 (2000), 241-89.

Kaplan, S.N., and P. Strömberg, "How Do Venture Capitalists Choose Investments?" Working Paper, University of Chicago Graduate School of Business (2001).

Kaplan, S.N., and P. Strömberg, P., "Financial Contracting Theory Meets the Real World: An Empirical Analysis of Venture Capital Contracts," Working Paper, University of Chicago Graduate School of Business (2002).

Kanniainen, V., and C. Keuschnigg, "The Optimal Portfolio of Start-up Firms in Venture Capital Finance," CESifo Working Paper No.381 (2000).

Kanniainen, V., and C. Keuschnigg, "Start-up Investment with Scarce Venture Capital Support," CESifo Working Paper No. 439 (2001).

Kirilenko, A., "Valuation and Control in Venture Finance," Journal of Finance 56 (2001): 565-587.

Kortum, S., and J. Lerner, "Assessing the Contribution of Venture Capital to Innovation," RAND Journal of Economics 31 (2000), 647-692.

Lerner, J., "The Syndication of Venture Capital Investments," Financial Management 23 (1994), 16-27.

Ljungqvist, A.P., "IPO Underpricing, Wealth Loss, and the Curious Role of Venture Capitalists in the Creation of Public Companies," Working Paper, New York University (1999).

MacIntosh J.G., "Venture Capital Exits in Canada and the United States," in P.J.N. Halpern, ed., Financing Growth in Canada, University of Calgary Press (1997), 279-356.

Maginart, S., K, De Waele, M. Wright, K. Robbie, P. Desbrières, H. Sapienza, and A. Beekman, "Venture Capital, Investment Appraisal, and Accounting Information: A Comparative Study of the US, UK, France, Belgium and Holland," European Financial Management 6 (2000), 380-404.

Marx, L., "Efficient Venture Capital Financing Combining Debt and Equity," Review of Economic Design 4 (1998), 371-87.

Mayer, C., K. Schoors, and Y. Yafeh, "Sources of Funds and Investment Activities of Venture Capital Funds: Evidence from Germany, Isreal, Japan and the U.K." Working Paper, Oxford University, University of Ghent and Hebrew University of Jerusalem (2002).

Megginson, W.L., and K.A. Weiss, "Venture Capitalist Certification in Initial Public Offerings," Journal of Finance 46 (1991), 879-903. 
Noe, T.H., and M.J. Rebello, “Asymmetric Information, Managerial Opportunism, Financing and Payout Policies," Journal of Finance 51 (1996), 637-60.

Petty, J.W., J.D. Martin, and J.W. Kensinger, Harvesting Investments in Private Companies. Morristown, N.J.: Financial Services Research Foundation, Inc. (1999).

Parhankangas, A., and D.G. Smith, "Conflict Management in the Entrepreneur-Venture Capital Relationship: An International Comparative Study," Working Paper, Northwestern School of Law of Lewis and Clark College and Helsinki University of Technology (2000).

Repullo, Rafael, and Javier Suarez, "Venture Capital Finance: A Security Design Approach," Working Paper, CEMFI, Madrid (1998).

Sahlman, W.A., "The Structure and Governance of Venture Capital Organizations," Journal of Financial Economics 27 (1990), 473-521.

Sahlman, W., H. Stevenson, M. Roberts, A. Bhidé, The Entrepreneurial Venture 2nd ed., Cambridge: Harvard Business School Press (1999).

Sandler, D., "The Tax Treatment of Employee Stock Options: Generous to a Fault," Canadian Tax Journal 49 (2001): 259-302.

Schindele, I., "Venture Capital with Multitask Monitoring: A Theory of Investment Syndication," Working Paper, University of Amsterdam (2002).

Schmidt, K.M., "Convertible Securities and Venture Capital Finance," Working Paper, University of Munich (2001).

Schweinbacher, A., "Innovation and Venture Capital Exits," Working Paper, University of Namur (2001).

Schweinbacher, A., "An Empirical Analysis of Venture Capital Exits in Europe and the United States," Working paper, University of Namur (2002).

Smith, D.G., "Control Over Exit in Venture Capital Relationships," Working Paper, Northwestern School of Law of Lewis and Clark College (2001).

Smith, J.K., and R.L. Smith, Entrepreneurial Finance, New York: Wiley (2000).

Songtao, L., "The Stage and Character of Venture Capital Development in Taiwan," Asia and Pacific Economics 3 (2000).

Szegö, G., "New Measures of Risk," Lecture Presented at the $14^{\text {th }}$ Annual Australasian Banking and Finance Conference, Sydney (2001).

Theil, H., "A Multinomial Logit Extension of the Linear Logit Model," International Economic Review 10 (1969), 251-259.

Trester, J.J., "Venture Capital Contracting under Asymmetric Information," Journal of Banking and Finance 22 (1998), 675-699. 


\begin{tabular}{|c|c|c|c|c|c|c|c|c|}
\hline \multicolumn{9}{|c|}{$\begin{array}{l}\text { Table 1a. Summary of the Data by Type of Security Used } \\
\begin{array}{l}\text { This table presents, by type of security used, the number of portfolio investees where the respondent VC was the lead investor, the number of financing rounds, the number of syndicated partners, and details } \\
\text { pertaining to board seats. }\end{array}\end{array}$} \\
\hline Type of Security & \begin{tabular}{|c|} 
Total \\
\# Investees \\
\end{tabular} & \begin{tabular}{|c|}
$\#$ Investees \\
As Lead Investor
\end{tabular} & $\begin{array}{l}\text { \# Financing } \\
\text { Rounds }\end{array}$ & $\begin{array}{l}\text { \# Syndicated } \\
\text { Investments }\end{array}$ & \begin{tabular}{|c|} 
Total \# \\
Syndicated Partners \\
\end{tabular} & $\begin{array}{c}\text { \# Respondent } \\
\text { VC Board Seats }\end{array}$ & $\begin{array}{c}\text { \# Syndicated } \\
\text { VC Board Seats }\end{array}$ & $\begin{array}{c}\text { \# Total } \\
\text { Board Seats }\end{array}$ \\
\hline Common Equity & 57 & 40 & 78 & 47 & 54 & 64 & 67 & 299 \\
\hline Conv. Preferred Equity & 24 & 12 & 32 & 13 & 24 & 22 & 17 & 99 \\
\hline Common + Conv. Preferred & 3 & 3 & 3 & 1 & 3 & 7 & 1 & 23 \\
\hline Common + Preferred & 19 & 13 & 20 & 9 & 9 & 17 & 10 & 68 \\
\hline Common + Conv. Preferred + Preferred & 1 & 1 & 2 & 1 & 3 & 2 & 4 & 9 \\
\hline Sum of Preferred + Common Equity & 23 & 17 & 25 & 11 & 15 & 26 & 15 & 100 \\
\hline Common + Conv. Debt & 6 & 5 & 8 & 2 & 2 & 8 & 3 & 31 \\
\hline Common + Conv. Debt + Preferred & 1 & 1 & 1 & 0 & 0 & 1 & 0 & 5 \\
\hline Conv. Debt + Preferred & 1 & 0 & 1 & 1 & 2 & 0 & 2 & 4 \\
\hline Conv. Debt + Preferred + Conv. Preferred & 1 & 1 & 1 & 1 & 2 & 2 & 2 & 6 \\
\hline Conv. Preferred + Debt & 5 & 4 & 13 & 2 & 3 & 7 & 4 & 18 \\
\hline Common + Preferred + Debt & 7 & 7 & 7 & 3 & 3 & 7 & 1 & 18 \\
\hline Common + Debt & 7 & 7 & 13 & 3 & 3 & 13 & 5 & 35 \\
\hline Sum of Debt + Common Equity & 28 & 25 & 44 & 12 & 15 & 38 & 17 & 117 \\
\hline Syndicated VCs Used Different Instrument? & 4 & 2 & 4 & 2 & 2 & 4 & 2 & 13 \\
\hline If yes, Syndicated VCs used Common Equity & 2 & 1 & 3 & 1 & 1 & 2 & 0 & 6 \\
\hline If yes, Syndicated VCs used Warrants & 2 & 1 & 1 & 1 & 1 & 2 & 2 & 7 \\
\hline TOTALS & 132 & 94 & 179 & 83 & 108 & 150 & 116 & 615 \\
\hline
\end{tabular}

\begin{tabular}{|c|c|c|c|c|c|c|c|c|c|c|c|}
\hline \multicolumn{12}{|c|}{ Table 1b. Summary of the Data by Type of Security Used } \\
\hline Type of Security & $\begin{array}{c}\text { Total } \\
\text { \# Investees } \\
\end{array}$ & $\begin{array}{c}\text { \# Investees } \\
\text { Seed }\end{array}$ & $\begin{array}{c}\text { \# Investees } \\
\text { Early }\end{array}$ & $\begin{array}{c}\text { \# Investees } \\
\text { Expansion } \\
\end{array}$ & $\begin{array}{c}\text { \# Investees } \\
\text { Late }\end{array}$ & $\begin{array}{l}\text { \# Investees } \\
\text { Turnaround } \\
\end{array}$ & $\begin{array}{c}\text { \# Investees } \\
\text { Buyout }\end{array}$ & $\begin{array}{l}\text { \# Investees } \\
\text { High-Tech }\end{array}$ & $\begin{array}{c}\text { \# Investees } \\
\text { Medical/Biotechnology } \\
\end{array}$ & \begin{tabular}{|c} 
\# Investees \\
Electronics/Computer \\
\end{tabular} & $\begin{array}{c}\text { \# Investees } \\
\text { Internet/Communication } \\
\end{array}$ \\
\hline Common Equity & 57 & 4 & 12 & 26 & 3 & 1 & 11 & 36 & 12 & 12 & 12 \\
\hline Conv. Preferred Equity & 24 & 7 & 10 & 6 & 0 & 0 & 1 & 20 & 3 & 3 & 14 \\
\hline Common + Conv. Preferred & 3 & 0 & 0 & 0 & 2 & 0 & 1 & 0 & 0 & 0 & 0 \\
\hline Common + Preferred & 19 & 1 & 3 & 4 & 0 & 0 & 11 & 9 & 4 & 3 & 2 \\
\hline Common + Conv. Preferred + Preferred & 1 & 0 & 0 & 0 & 0 & 0 & 1 & 0 & 0 & 0 & 0 \\
\hline Sum of Preferred + Common Equity & 23 & 1 & 3 & 4 & 2 & 0 & 13 & 9 & 4 & 3 & 2 \\
\hline Common + Conv. Debt & 6 & 1 & 0 & 5 & 0 & 0 & 0 & 2 & 0 & 0 & 2 \\
\hline Common + Conv. Debt + Preferred & 1 & 0 & 0 & 1 & 0 & 0 & 0 & 1 & 0 & 1 & 0 \\
\hline Conv. Debt + Preferred & 1 & 0 & 0 & 1 & 0 & 0 & 0 & 0 & 0 & 0 & 0 \\
\hline Conv. Debt + Preferred + Conv. Preferred & 1 & 0 & 0 & 0 & 0 & 0 & 1 & 0 & 0 & 0 & 0 \\
\hline Conv. Preferred + Debt & 5 & 4 & 0 & 0 & 0 & 1 & 0 & 5 & 0 & 1 & 4 \\
\hline Common + Preferred + Debt & 7 & 0 & 0 & 0 & 0 & 0 & 7 & 2 & 0 & 2 & 0 \\
\hline Common + Debt & 7 & 0 & 2 & 0 & 0 & 0 & 5 & 3 & 1 & 2 & 0 \\
\hline Sum of Debt + Common Equity & 28 & 5 & 2 & 7 & 0 & 1 & 13 & 13 & 1 & 6 & 6 \\
\hline Syndicated VCs Used Different Instrument? & 4 & 0 & 2 & 0 & 0 & 0 & 0 & 1 & 0 & 1 & 0 \\
\hline If yes, Syndicated VCs used Common Equity & 2 & 0 & 1 & 0 & 0 & 0 & 0 & 1 & 0 & 1 & 0 \\
\hline If yes, Syndicated VCs used Warrants & 2 & 0 & 1 & 0 & 0 & 0 & 0 & 0 & 0 & 0 & 0 \\
\hline TOTALS & 132 & 17 & 27 & 43 & 5 & 2 & 38 & 78 & 20 & 24 & 34 \\
\hline
\end{tabular}

\begin{tabular}{|c|c|c|c|c|c|c|c|c|c|}
\hline Type of Security & $\begin{array}{c}\text { Total } \\
\text { \# Investees } \\
\end{array}$ & $\begin{array}{l}\text { Total \# Actual } \\
\text { Exits Reported }\end{array}$ & $\begin{array}{c}\text { Total \# Expected } \\
\text { Exits Reported }\end{array}$ & $\begin{array}{c}\text { Total \# } \\
\text { Actual IPO } \\
\end{array}$ & $\begin{array}{c}\text { Total \# } \\
\text { Expected IPO } \\
\end{array}$ & $\begin{array}{l}\text { Total \# Actual } \\
\text { Acquisitions }\end{array}$ & $\begin{array}{c}\text { Total \# Expected } \\
\text { Acquisitions }\end{array}$ & $\begin{array}{c}\text { Total \# Actual } \\
\text { Write-offs }\end{array}$ & $\begin{array}{c}\text { Total \# Expected } \\
\text { Write-downs }\end{array}$ \\
\hline Common Equity & 57 & 16 & 14 & 8 & 7 & 4 & 7 & 4 & 0 \\
\hline Conv. Preferred Equity & 24 & 5 & 11 & 0 & 3 & 2 & 8 & 3 & 0 \\
\hline Common + Conv. Preferred & 3 & 0 & 3 & 0 & 1 & 0 & 2 & 0 & 0 \\
\hline Common + Preferred & 19 & 5 & 3 & 0 & 0 & 3 & 3 & 2 & 0 \\
\hline Common + Conv. Preferred + Preferred & 1 & 1 & 0 & 1 & 0 & 0 & 0 & 0 & 0 \\
\hline Sum of Preferred + Common Equity & 23 & 6 & 6 & 1 & 1 & 3 & 5 & 2 & 0 \\
\hline Common + Conv. Debt & 6 & 0 & 1 & 0 & 0 & 0 & 1 & 0 & 0 \\
\hline Common + Conv. Debt + Preferred & 1 & 0 & 0 & 0 & 0 & 0 & 0 & 0 & 0 \\
\hline Conv. Debt + Preferred & 1 & 1 & 0 & 0 & 0 & 1 & 0 & 0 & 0 \\
\hline Conv. Debt + Preferred + Conv. Preferred & 1 & 0 & 0 & 0 & 0 & 0 & 0 & 0 & 0 \\
\hline Conv. Preferred + Debt & 5 & 1 & 4 & 0 & 1 & 0 & 2 & 1 & 1 \\
\hline Common + Preferred + Debt & 7 & 2 & 0 & 0 & 0 & 2 & 0 & 0 & 0 \\
\hline Common + Debt & 7 & 2 & 2 & 1 & 0 & 1 & 2 & 0 & 0 \\
\hline Sum of Debt + Common Equity & 28 & 6 & 7 & 1 & 1 & 4 & 5 & 1 & 1 \\
\hline Syndicated VCs Used Different Instrument? & 4 & 1 & 1 & 1 & 1 & 0 & 0 & 0 & 0 \\
\hline If yes, Syndicated VCs used Common Equity & 2 & 1 & 0 & 1 & 0 & 0 & 0 & 0 & 0 \\
\hline If yes, Syndicated VCs used Warrants & 2 & 0 & 1 & 0 & 1 & 0 & 0 & 0 & 0 \\
\hline TOTALS & 132 & 33 & 38 & 10 & 12 & 13 & 25 & 10 & 1 \\
\hline
\end{tabular}




\begin{tabular}{|c|c|c|c|c|c|c|c|c|}
\hline This table presents, by type of security used. & , the number o & $\begin{array}{r}\mathrm{Ta} \\
\text { ff portfolio investees invo } \\
\text { ctions, and sale of share }\end{array}$ & $\begin{array}{l}\text { ble 1d. Summary of the Dat } \\
\text { olving covenants allowing futu } \\
\text { es. The party for which the co }\end{array}$ & $\begin{array}{l}\text { ta by Type of Security } \\
\text { ure equity allocation to be } \\
\text { ontingent equity was dire }\end{array}$ & $\begin{array}{l}\text { Used } \\
\text { e contingent on } \\
\text { ectly granted is a }\end{array}$ & $\begin{array}{l}\text { measures of financial p } \\
\text { Iso reported. }\end{array}$ & erformance, non-financial perf & rmance, certair \\
\hline & Total & & \# Contracts with conting & jencies on... & & \# Co & ntracts with contingencies for. & \\
\hline Type of Security & \# Investees & Financial Performance & Non-Financial Performance & Certain Actions Taken & Sale of Shares & Reporting VC Fund & Other Syndicated VC Fund & Entrepreneur \\
\hline Common Equity & 57 & 14 & 11 & 10 & 5 & 10 & 9 & 19 \\
\hline Conv. Preferred Equity & 24 & 17 & 10 & 9 & 8 & 11 & 5 & 10 \\
\hline Common + Conv. Preferred & 3 & 1 & 0 & 1 & 3 & 3 & 0 & 3 \\
\hline Common + Preferred & 19 & 3 & 2 & 2 & 0 & 1 & 3 & 3 \\
\hline Common + Conv. Preferred + Preferred & 1 & 1 & 0 & 0 & 0 & 0 & 0 & 1 \\
\hline Sum of Preferred + Common Equity & 23 & 5 & 2 & 3 & 3 & 4 & 3 & 7 \\
\hline Common + Conv. Debt & 6 & 3 & 1 & 1 & 0 & 3 & 0 & 2 \\
\hline Common + Conv. Debt + Preferred & 1 & 0 & 0 & 0 & 0 & 0 & 0 & 0 \\
\hline Conv. Debt + Preferred & 1 & 1 & 0 & 0 & 0 & 0 & 0 & 1 \\
\hline Conv. Debt + Preferred + Conv. Preferred & 1 & 1 & 0 & 1 & 0 & 0 & 0 & 1 \\
\hline Conv. Preferred + Debt & 5 & 3 & 3 & 1 & 0 & 3 & 1 & 0 \\
\hline Common + Preferred + Debt & 7 & 0 & 0 & 0 & 0 & 0 & 0 & 0 \\
\hline Common + Debt & 7 & 1 & 0 & 0 & 3 & 2 & 0 & 1 \\
\hline Sum of Debt + Common Equity & 28 & 9 & 4 & 3 & 3 & 8 & 1 & 5 \\
\hline Syndicated VCs Used Different Instrument? & 4 & 1 & 0 & 0 & 2 & 1 & 0 & 1 \\
\hline If yes, Syndicated VCs used Common Equity & 2 & 0 & 0 & 0 & 1 & 0 & 0 & 1 \\
\hline If yes, Syndicated VCs used Warrants & 2 & 1 & 0 & 0 & 1 & 1 & 0 & 0 \\
\hline TOTALS & 132 & 45 & 27 & 25 & 19 & 33 & 18 & 41 \\
\hline
\end{tabular}

\begin{tabular}{|c|c|c|c|c|c|c|c|c|c|}
\hline \multicolumn{10}{|c|}{$\begin{array}{l}\text { Table 1e. Summary of the Data by Type of Security Used } \\
\begin{array}{l}\text { This table presents, by type of security used, the number of investments for which veto rights were used pertaining to asset sales, asset purchases, changes in control, and issuance of equity. State contingent changes in VC } \\
\text { ownership percentage and VC board seats for each fund are also reported. }\end{array}\end{array}$} \\
\hline & Total & \multicolumn{5}{|c|}{ \# Investees for which specific veto rights used... } & \multirow{2}{*}{\begin{tabular}{|c|} 
Average \\
$\%$ Ownership \\
\end{tabular}} & \multirow{2}{*}{$\begin{array}{c}\text { Increase in VC Equity } \\
\text { if poor performance } \\
\end{array}$} & \multirow{2}{*}{$\begin{array}{l}\text { Increase in VC board seats } \\
\text { if poor performance }\end{array}$} \\
\hline Type of Security & \# Investees & Asset Sales & Asset Purchases & Changes in Control & Issuance of Equity & Other & & & \\
\hline Common Equity & 57 & 24 & 25 & 31 & 30 & 32 & $33.5 \%$ & 14 & 11 \\
\hline Conv. Preferred Equity & 24 & 21 & 19 & 21 & 20 & 14 & $19.6 \%$ & 7 & 6 \\
\hline Common + Conv. Preferred & 3 & 3 & 3 & 3 & 3 & 3 & $57.7 \%$ & 0 & 0 \\
\hline Common + Preferred & 19 & 14 & 14 & 16 & 16 & 16 & $36.6 \%$ & 4 & 4 \\
\hline Common + Conv. Preferred + Preferred & 1 & 1 & 1 & 1 & 1 & 0 & $26.0 \%$ & 0 & 0 \\
\hline Sum of Preferred + Common Equity & 23 & 18 & 18 & 20 & 20 & 19 & $38.9 \%$ & 4 & 4 \\
\hline Common + Conv. Debt & 6 & 1 & 1 & 1 & 1 & 1 & $46.4 \%$ & 0 & 0 \\
\hline Common + Conv. Debt + Preferred & 1 & 1 & 1 & 1 & 1 & 1 & $38.6 \%$ & 0 & 0 \\
\hline Conv. Debt + Preferred & 1 & 1 & 1 & 1 & 1 & 0 & $11.0 \%$ & 0 & 0 \\
\hline Conv. Debt + Preferred + Conv. Preferred & 1 & 1 & 1 & 1 & 1 & 1 & $25.0 \%$ & 0 & 0 \\
\hline Conv. Preferred + Debt & 5 & 5 & 4 & 4 & 4 & 4 & $57.8 \%$ & 0 & 0 \\
\hline Common + Preferred + Debt & 7 & 7 & 7 & 7 & 7 & 7 & $50.7 \%$ & 0 & 0 \\
\hline Common + Debt & 10 & 5 & 5 & 6 & 4 & 4 & $44.8 \%$ & 0 & 0 \\
\hline Sum of Debt + Common Equity & 31 & 21 & 20 & 21 & 19 & 18 & $46.8 \%$ & 0 & 0 \\
\hline Syndicated VCs Used Different Instrument? & 4 & 1 & 1 & 1 & 0 & 1 & $11.3 \%$ & 1 & 0 \\
\hline If yes, Syndicated VCs used Common Equity & 2 & 0 & 0 & 1 & 0 & 0 & $10.5 \%$ & 0 & 0 \\
\hline If yes, Syndicated VCs used Warrants & 2 & 1 & 1 & 0 & 0 & 1 & $12.1 \%$ & 1 & 0 \\
\hline TOTALS & 135 & 84 & 82 & 93 & 89 & 83 & $35.0 \%$ & 25 & 21 \\
\hline
\end{tabular}

\begin{tabular}{|c|c|c|c|c|c|c|c|c|c|c|c|}
\hline Type of Security & \begin{tabular}{c|} 
Total \\
\# Investees \\
\#
\end{tabular} & $\begin{array}{c}\text { Right to } \\
\text { replace CEO }\end{array}$ & \begin{tabular}{|l|}
$\begin{array}{c}\text { Automatic conver- } \\
\text { sion rights in IPO }\end{array}$ \\
\end{tabular} & $\begin{array}{c}\begin{array}{c}\text { First refusal } \\
\text { in sale }\end{array} \\
\end{array}$ & \begin{tabular}{|c|} 
co-sale \\
agreement
\end{tabular} & \begin{tabular}{|c|}
$\begin{array}{c}\text { Antidillution } \\
\text { protection }\end{array}$ \\
\end{tabular} & \begin{tabular}{|l|} 
Protection rights \\
against new issue \\
\end{tabular} & \begin{tabular}{|c|}
$\begin{array}{c}\text { Redemption } \\
\text { rights }\end{array}$ \\
\end{tabular} & $\begin{array}{c}\begin{array}{c}\text { Information } \\
\text { rights }\end{array} \\
\end{array}$ & $\begin{array}{l}\text { Demand regi- } \\
\text { stration rights }\end{array}$ & $\begin{array}{l}\text { Piggyback regi- } \\
\text { stration rights }\end{array}$ \\
\hline Common Equity & 57 & 15 & 0 & 25 & 29 & 25 & 22 & 19 & 27 & 5 & 2 \\
\hline Conv. Preferred Equity & 24 & 4 & 3 & 20 & 13 & 13 & 18 & 3 & 19 & 10 & 7 \\
\hline Common + Conv. Preferred & 3 & 2 & 3 & 0 & 3 & 2 & 3 & 0 & 3 & 0 & 0 \\
\hline Common + Preferred & 19 & 12 & 0 & 4 & 14 & 14 & 14 & 14 & 14 & 8 & 8 \\
\hline Common + Conv. Preferred + Preferred & 1 & 1 & 1 & 1 & 1 & 0 & 0 & 0 & 1 & 1 & 0 \\
\hline Sum of Preferred + Common Equity & 23 & 15 & 4 & 5 & 18 & 16 & 17 & 14 & 18 & 9 & 8 \\
\hline Common + Conv. Debt & 6 & 1 & 1 & 2 & 1 & 1 & 0 & 0 & 2 & 2 & 0 \\
\hline Common + Conv. Debt + Preferred & 1 & 0 & 0 & 0 & 1 & 1 & 1 & 1 & 1 & 0 & 0 \\
\hline Conv. Debt + Preferred & 1 & 1 & 1 & 1 & 1 & 0 & 0 & 0 & 1 & 1 & 0 \\
\hline Conv. Debt + Preferred + Conv. Preferred & 1 & 1 & 1 & 1 & 1 & 0 & 0 & 0 & 1 & 1 & 0 \\
\hline Conv. Preferred + Debt & 5 & 0 & 0 & 4 & 4 & 4 & 5 & 0 & 4 & 0 & 0 \\
\hline Common + Preferred + Debt & 7 & 7 & 0 & 0 & 7 & 7 & 7 & 7 & 7 & 7 & 7 \\
\hline Common + Debt & 7 & 3 & 0 & 2 & 6 & 4 & 5 & 4 & 7 & 3 & 3 \\
\hline Sum of Debt + Common Equity & 28 & 13 & 3 & 10 & 21 & 17 & 18 & 12 & 23 & 14 & 10 \\
\hline Syndicated VCs Used Different Instrument? & 4 & 0 & 0 & 1 & 2 & 0 & 1 & 0 & 2 & 0 & 0 \\
\hline If yes, Syndicated VCs used Common Equity & 2 & 0 & 0 & 1 & 1 & 0 & 1 & 0 & 1 & 0 & 0 \\
\hline If yes, Syndicated VCs used Warrants & 2 & 0 & 0 & 0 & 1 & 0 & 0 & 0 & 1 & 0 & 0 \\
\hline TOTALS & 132 & 47 & 10 & 60 & 81 & 71 & 75 & 48 & 87 & 38 & 27 \\
\hline
\end{tabular}


Table 2a. Summary of the Data by Exit Vehicle

This table presents, by exit vehicle, the number of divestments (actual and expected), the internal rate of retun (IRR) (expected exit as at 9/2001), ownership percentages, control over exit, conflicts over exit, type of security, stage of development at first investment, \# rounds, \# syndicated VCs, and board seats.

\begin{tabular}{|c|c|c|c|c|c|c|}
\hline & Actual IPOs & Expected IPOs & Actual Acquisitions & Expected Acquisitions & Actual Write-offs & Expected Write-downs \\
\hline Average IRR & $95.90 \%$ & $23.25 \%$ & $128.54 \%$ & $7.09 \%$ & $-100.00 \%$ & $0.00 \%$ \\
\hline Standard Deviation IRR & $142.00 \%$ & $44.76 \%$ & $149.34 \%$ & $65.64 \%$ & $0.00 \%$ & $0.00 \%$ \\
\hline Max IRR & $500.00 \%$ & $115.61 \%$ & $566.00 \%$ & $91.27 \%$ & $-100.00 \%$ & $0.00 \%$ \\
\hline Min IRR & $30.00 \%$ & $0.00 \%$ & $27.00 \%$ & $-91.89 \%$ & $-100.00 \%$ & $0.00 \%$ \\
\hline Average Respondent VC Ownership \% & $54.22 \%$ & $20.62 \%$ & $44.73 \%$ & $41.85 \%$ & $27.26 \%$ & $10.00 \%$ \\
\hline Average Syndicated VC Ownership \% & $11.25 \%$ & $11.09 \%$ & $15.30 \%$ & $12.88 \%$ & $14.13 \%$ & $20.00 \%$ \\
\hline Preplanned Exit & 5 & 11 & 9 & 21 & 0 & 0 \\
\hline Unsolicited Offer & 0 & 0 & 3 & 1 & 0 & 0 \\
\hline Market Conditions & 6 & 0 & 1 & 4 & 1 & 0 \\
\hline Internal Conflicts & 0 & 0 & 0 & 0 & 7 & 0 \\
\hline VC Fundraising & 0 & 1 & 0 & 1 & 0 & 0 \\
\hline Fund Termination & 0 & 1 & 0 & 0 & 0 & 0 \\
\hline Other & 0 & 0 & 0 & 0 & 2 & 1 \\
\hline Vc Controls Exit & 8 & 6 & 10 & 20 & 8 & 0 \\
\hline Syndicated VC Controls Exit & 1 & 2 & 0 & 1 & 2 & 0 \\
\hline Entrepreneur Controls Exit & 1 & 4 & 3 & 4 & 0 & 1 \\
\hline Conflict re timing & 5 & 0 & 1 & 2 & 0 & 0 \\
\hline Conflict re valuation & 1 & 0 & 0 & 0 & 0 & 0 \\
\hline Common Equity & 8 & 7 & 4 & 7 & 4 & 0 \\
\hline Convertible Preferred Equity & 0 & 3 & 2 & 8 & 2 & 0 \\
\hline Mixed Preferred + Common & 1 & 1 & 3 & 5 & 2 & 0 \\
\hline Mixed Debt + Common & 1 & 1 & 4 & 5 & 2 & 1 \\
\hline Seed & 0 & 1 & 1 & 6 & 3 & 0 \\
\hline Early & 1 & 3 & 1 & 4 & 2 & 0 \\
\hline Expansion & 4 & 6 & 5 & 6 & 5 & 0 \\
\hline Late & 1 & 2 & 0 & 1 & 0 & 0 \\
\hline Turnaround & 0 & 0 & 0 & 0 & 0 & 1 \\
\hline Buyout & 4 & 0 & 6 & 8 & 0 & 0 \\
\hline High-Tech & 6 & 8 & 7 & 15 & 8 & 1 \\
\hline Medical/Biotech & 1 & 1 & 3 & 1 & 2 & 0 \\
\hline Electronic/Computer & 3 & 0 & 0 & 4 & 0 & 1 \\
\hline Communication/Internet & 2 & 7 & 4 & 10 & 6 & 0 \\
\hline Non-Tech Industries & 4 & 4 & 6 & 10 & 2 & 0 \\
\hline Average \# Rounds & 2.5 & 1.25 & 1.77 & 1.48 & 1 & 4 \\
\hline Average \# Syndicated Partners & 1.2 & 1 & 1 & 0.76 & 1.1 & 2 \\
\hline Average \# Respondent VC Board Seats & 2 & 1.08 & 1.46 & 1.44 & 1.1 & 1 \\
\hline Average \# Syndicated VC Board Seats & 1.1 & 0.75 & 0.69 & 0.8 & 1 & 2 \\
\hline Average \# Total Board Seats & 6 & 5.75 & 3.92 & 4.72 & 4.6 & 6 \\
\hline Total \# Exits & 10 & 12 & 13 & 25 & 10 & 1 \\
\hline
\end{tabular}


Table 2b. Summary of the Data by Exit Vehicle

This table presents, by exit vehicle, the number of divestments (actual and expected), the contractual contingencies (incentives for the entrepreneur, respondent VC, and syndicated VCs), veto rights, contingent equity ownership and board seats, and control rights.

\begin{tabular}{|c|c|c|c|c|c|c|}
\hline & Actual IPOs & Expected IPOs & Actual Acquisitions & Expected Acquisitions & Actual Write-offs & Expected Write-downs \\
\hline Financial Contingencies - Entrepreneur & 1 & 3 & 1 & 10 & 0 & 0 \\
\hline Non-Financial Contingencies - Entrepreneur & 0 & 3 & 0 & 8 & 0 & 0 \\
\hline Certain Actions Contingencies - Entrepreneur & 0 & 3 & 0 & 2 & 0 & 0 \\
\hline Sale of Shares Contingencies - Entrepreneur & 1 & 2 & 0 & 3 & 0 & 0 \\
\hline Financial Contingencies - Respondent VC & 0 & 3 & 0 & 8 & 0 & 0 \\
\hline Non-Financial Contingencies - Respondent VC & 0 & 3 & 0 & 8 & 0 & 0 \\
\hline Certain Actions Contingencies - Respondent VC & 0 & 3 & 0 & 4 & 0 & 0 \\
\hline Sale of Shares Contingencies - Respondent VC & 0 & 5 & 0 & 5 & 0 & 0 \\
\hline Financial Contingencies - Syndicated VC & 0 & 1 & 0 & 4 & 0 & 0 \\
\hline Non-Financial Contingencies - Syndicated VC & 0 & 1 & 0 & 3 & 0 & 0 \\
\hline Certain Actions Contingencies - Syndicated VC & 0 & 1 & 0 & 3 & 0 & 0 \\
\hline Sale of Shares Contingencies - Syndicate VC & 0 & 0 & 0 & 0 & 0 & 0 \\
\hline Veto Rights re Asset Sales & 8 & 7 & 11 & 20 & 6 & 1 \\
\hline Veto Rights re Asset Purchases & 8 & 7 & 11 & 19 & 6 & 0 \\
\hline Veto Rights re Changes in Control & 9 & 5 & 11 & 21 & 6 & 0 \\
\hline Veto Rights re Issuance of Equity & 8 & 5 & 11 & 18 & 6 & 0 \\
\hline Veto Rights re Other & 7 & 7 & 10 & 18 & 6 & 0 \\
\hline Increase VC \% ownership if poor performance & 7 & 2 & 5 & 6 & 3 & 0 \\
\hline Increase VC board seats if poor performance & 7 & 0 & 5 & 0 & 3 & 0 \\
\hline Right to replace CEO & 8 & 0 & 10 & 10 & 3 & 0 \\
\hline Automatic conversion upon IPO & 1 & 1 & 1 & 6 & 0 & 0 \\
\hline Right of first refusal in sale & 8 & 6 & 7 & 22 & 6 & 0 \\
\hline Co-sale agreement & 9 & 7 & 11 & 20 & 6 & 0 \\
\hline Antidillution & 7 & 3 & 10 & 20 & 6 & 0 \\
\hline Protection rights in new issues & 8 & 5 & 10 & 15 & 6 & 1 \\
\hline Redemption rights & 7 & 0 & 9 & 2 & 3 & 0 \\
\hline Information rights & 9 & 8 & 11 & 24 & 6 & 0 \\
\hline Demand registration rights & 1 & 1 & 5 & 9 & 0 & 0 \\
\hline Piggyback registration rights & 0 & 0 & 4 & 4 & 0 & 0 \\
\hline Total \# Exits & 10 & 12 & 13 & 25 & 10 & 1 \\
\hline
\end{tabular}




\begin{tabular}{|c|c|c|c|c|c|c|c|c|}
\hline & & & & & & & & \\
\hline & Correlation Coeficient & fuity & $\begin{array}{l}\text { Convertible Preferre } \\
\text { Correlation Coeficient }\end{array}$ & red Equity & Preferred and Com & Imon Equity & Debt and/or Preferred a & and Common \\
\hline & & & & & & & & \\
\hline Contract contingent on financial performance $-\mathrm{VC}$ incentives & -0.308 & $12.505^{\star \star \star *}$ & 0.369 & $17.967^{\star \star \star}$ & -0.097 & 1.242 & 0.242 & $7.735^{\star \star \star *}$ \\
\hline Contract contract on non-financial performance - $-\mathrm{VC}$ incentives & -0.134 & 2.376 & 0.174 & $3.987^{\star \star}$ & -0.179 & 0.000 & 0.299 & $11.801^{\star \star * *}$ \\
\hline Contract contingent on certain actions being taken -- $\mathrm{VC}$ incentives & -0.175 & $4.049^{* *}$ & 0.262 & $9.069^{* \star *}$ & -0.075 & 0.742 & 0.102 & 1.375 \\
\hline Contract contingent on sale of securities - $-\mathrm{VC}$ incentives & -0.168 & $3.732^{*}$ & 0.271 & $9.663^{* * *}$ & 0.048 & 0.303 & -0.065 & 0.561 \\
\hline Contract contingent on financial performance - Entrepreneur incentives & -0.108 & 1.536 & 0.206 & $5.618^{* *}$ & 0.002 & 0.000 & 0.016 & 0.034 \\
\hline Contract contract on non-financial performance - Entrepreneur incentives & 0.003 & 0.001 & 0.146 & $2.811^{\star}$ & -0.058 & 0.452 & -0.029 & 0.107 \\
\hline Contract contingent on certain actions being taken -- Entrepreneur incentives & 0.016 & 0.032 & 0.075 & 0.737 & -0.078 & 0.801 & 0.060 & 0.480 \\
\hline Contract contingent on sale of securities -- Entrepreneur incentives & -0.152 & $3.057^{*}$ & 0.142 & 2.667 & 0.098 & 1.271 & -0.015 & 0.029 \\
\hline Contract contingent on financial performance (all) & -0.258 & $8.806^{\star \star \star}$ & 0.370 & $18.031^{\star \star \star}$ & -0.080 & 0.843 & 0.194 & $4.951^{* \star}$ \\
\hline Contract contract on non-financial performance (all) & -0.108 & 1.535 & 0.260 & $8.917^{* \star *}$ & -0.122 & 1.951 & 0.107 & 1.504 \\
\hline Contract contingent on certain actions being taken (all) & -0.070 & 0.648 & 0.223 & $6.582^{* * *}$ & -0.124 & 2.021 & 0.085 & 0.946 \\
\hline Contract contingent on sale of securities (all) & -0.183 & $4.440^{* *}$ & 0.254 & $8.539^{* * *}$ & 0.087 & 0.990 & -0.071 & 0.668 \\
\hline $\mathrm{VC}$ has veto over asset sales & -0.487 & $31.263^{\star \star \star \star}$ & 0.250 & $8.250^{\star \star *}$ & 0.230 & $6.988^{\star \star \star *}$ & 0.035 & 0.160 \\
\hline $\mathrm{VC}$ has veto over asset purchases & -0.422 & $23.468^{\text {t+*t+}}$ & 0.180 & $4.271^{\star \star}$ & 0.245 & $7.915^{* * *}$ & -0.006 & 0.005 \\
\hline VC has veto over changes in control & -0.412 & $22.389^{*+* t}$ & 0.194 & $4.977^{* *}$ & 0.285 & $10.708^{*+*}$ & -0.072 & 0.680 \\
\hline VC has veto over issuance of equity & -0.374 & $18.471^{\star \star *+}$ & 0.176 & $4.094^{* \star}$ & 0.232 & $7.125^{* * *}$ & -0.047 & 0.286 \\
\hline VC has veto over other decisions & -0.197 & $5.121^{* \star *}$ & -0.026 & 0.091 & 0.245 & $7.915^{* * *}$ & -0.110 & 1.584 \\
\hline VC ownership percentage $>50 \%$ & -0.084 & 0.927 & -0.286 & $10.779^{* \star \star}$ & 0.163 & $3.510^{*}$ & 0.128 & 2.165 \\
\hline VC ownership percentage $<50 \%$ & 0.084 & 0.927 & 0.286 & $10.779^{* * *}$ & -0.163 & $3.510^{*}$ & -0.128 & 2.165 \\
\hline VC equity ownership percentage increases if bad performance & 0.055 & 0.393 & 0.129 & 2.210 & 0.018 & 0.042 & -0.183 & 0.000 \\
\hline VC's Board Seats / Total Board Seats $>50 \%$ & -0.045 & 0.263 & -0.044 & 0.255 & -0.038 & 0.193 & 0.187 & $4.592^{* *}$ \\
\hline VC's Board Seats / Total Board Seats $<50 \%$ & 0.045 & 0.263 & 0.044 & 0.255 & 0.038 & 0.193 & -0.187 & $4.592^{* *}$ \\
\hline VC's board seats increase if bad performance & 0.081 & 0.861 & 0.117 & 1.812 & -0.038 & 0.193 & -0.150 & 0.000 \\
\hline VC has right to replace CEO & -0.233 & $7.187^{* \star *}$ & -0.179 & $4.233^{\text {t* }}$ & 0.377 & $18.731^{\star \star \star}$ & -0.127 & 2.117 \\
\hline VC shares auutomatically convert upon IPO & -0.263 & 0.000 & 0.142 & 2.667 & 0.098 & 1.271 & 0.163 & $3.516^{*}$ \\
\hline VC has right of first refusal & -0.081 & 0.859 & 0.368 & $17.877^{\star \star * *}$ & -0.164 & $3.568^{*}$ & 0.060 & 0.470 \\
\hline VC has co-sale agreement & -0.246 & $7.994^{* * *}$ & -0.060 & 0.470 & 0.290 & $11.102^{* * *}$ & -0.052 & 0.359 \\
\hline VC has antidilution provision & -0.228 & $6.866^{* \star *}$ & 0.014 & 0.027 & 0.217 & $6.234^{* *}$ & -0.097 & 1.244 \\
\hline $\mathrm{VC}$ has protection rights against new issues & -0.378 & $18.855^{\text {t*t+ }}$ & 0.186 & $4.556^{\star *}$ & 0.260 & $8.911^{* * *+}$ & -0.119 & 1.882 \\
\hline VC has redemption rights & -0.055 & 0.398 & -0.234 & $7.219^{* \star *}$ & 0.266 & $9.373^{* *+}$ & -0.209 & $5.779^{* *}$ \\
\hline VC has information rights in operating plans and financials & -0.406 & $21.800^{* * *}$ & 0.147 & $2.838^{\star}$ & 0.286 & $10.789^{\text {t**}}$ & -0.035 & 0.158 \\
\hline VC has demand registration rights & -0.431 & $24.561^{\star * *+}$ & 0.142 & 2.656 & 0.212 & $5.916^{* \star}$ & -0.024 & 0.076 \\
\hline VC has piggyback registration rights & -0.386 & $19.676^{*+*+}$ & 0.100 & 1.320 & 0.284 & $10.630^{* * *}$ & -0.195 & 0.000 \\
\hline VC has control over exit & -0.128 & 2.174 & -0.175 & $4.035^{* *}$ & 0.334 & $14.688^{* * *}$ & -0.170 & $3.796^{*}$ \\
\hline Other syndicated VC has control over exit & 0.290 & $11.090^{* * *}$ & -0.098 & 1.258 & -0.137 & 2.479 & -0.083 & 0.900 \\
\hline Founder has control over exit & -0.101 & 1.335 & 0.283 & $10.597^{* * *}$ & -0.265 & $9.242^{* * *}$ & 0.264 & $9.230^{* * *}$ \\
\hline Respondent is Lead VC & -0.097 & 1.245 & -0.227 & $6.790^{\star \star *}$ & 0.230 & $6.959^{\star \star *}$ & 0.028 & 0.107 \\
\hline Syndication & 0.329 & $14.274^{* * *}$ & -0.101 & 1.338 & -0.125 & 2.072 & -0.155 & $3.168^{*}$ \\
\hline Seed & -0.107 & 1.508 & 0.229 & $6.936^{* \star *}$ & -0.155 & $3.153^{*}$ & 0.161 & $3.437^{*}$ \\
\hline Early & 0.013 & 0.022 & 0.248 & $8.112^{\star \star *}$ & -0.051 & 0.342 & -0.175 & 0.000 \\
\hline Expansion & 0.210 & $5.816^{\star \star}$ & -0.076 & 0.766 & -0.223 & $6.545^{* *}$ & 0.181 & $4.303^{* *}$ \\
\hline Late & 0.067 & 0.599 & -0.094 & 0.000 & 0.082 & 0.883 & -0.068 & 0.000 \\
\hline Turnaround & 0.017 & 0.038 & -0.058 & 0.000 & -0.067 & 0.000 & 0.159 & $3.324^{*}$ \\
\hline Buyout & -0.183 & $4.407^{\star *}$ & -0.256 & $8.674^{* * *}$ & 0.374 & $18.449^{* * *}$ & -0.165 & $3.579^{*}$ \\
\hline High-Tech & 0.072 & 0.686 & 0.232 & $7.131^{\star \star *}$ & -0.211 & $5.853^{* \star}$ & -0.014 & 0.025 \\
\hline Medical/Biotech & 0.143 & $2.717^{\star}$ & -0.035 & 0.160 & 0.023 & 0.069 & -0.146 & 0.000 \\
\hline Electronic/Computer & 0.065 & 0.556 & -0.069 & 0.637 & -0.021 & 0.060 & -0.035 & 0.160 \\
\hline Communication/Internet & -0.094 & 1.161 & 0.351 & $16.278^{*+*}$ & -0.237 & $7.399^{\star \star \star *}$ & 0.135 & 2.395 \\
\hline
\end{tabular}




\begin{tabular}{|c|c|c|c|c|c|c|}
\hline & \multicolumn{2}{|c|}{ Actual \& Expected IPOs } & \multicolumn{2}{|c|}{ Actual \& Expected Acquisitions } & \multicolumn{2}{|c|}{ Actual Writeoffs \& Expected Writedowns } \\
\hline & Correlation Coeficient & Chi-squared & Correlation Coeficient & Chi-squared & Correlation Coeficient & Chi-squared \\
\hline Common Equity & 0.352 & $8.783^{\star \star \star}$ & -0.289 & $5.933^{\star \star}$ & -0.163 & 1.894 \\
\hline Convertible Preferred Equity & -0.123 & 1.073 & 0.136 & 1.321 & -0.014 & 0.014 \\
\hline Mixes of Preferred and Common Equity & -0.143 & 1.446 & 0.165 & 1.926 & 0.134 & 1.270 \\
\hline Mixes of Debt and Common Equity & -0.142 & 1.441 & -0.025 & 0.045 & 0.143 & 1.450 \\
\hline Contract contingent on financial performance -- VC incentives & -0.034 & 0.084 & 0.165 & 1.930 & -0.222 & 0.000 \\
\hline Contract contract on non-financial performance -- VC incentives & -0.034 & 0.084 & 0.165 & 1.930 & -0.222 & 0.000 \\
\hline Contract contingent on certain actions being taken -- VC incentives & 0.085 & 0.512 & 0.024 & 0.041 & -0.171 & 0.000 \\
\hline Contract contingent on sale of securities - VC incentives & 0.166 & 1.968 & -0.029 & 0.058 & -0.210 & 0.000 \\
\hline Contract contingent on financial performance -- Entrepreneur incentives & -0.048 & 0.166 & 0.206 & $3.001^{*}$ & 0.070 & 0.350 \\
\hline Contract contract on non-financial performance -- Entrepreneur incentives & -0.034 & 0.084 & 0.165 & 1.930 & 0.064 & 0.295 \\
\hline Contract contingent on certain actions being taken -- Entrepreneur incentives & 0.173 & 2.117 & -0.075 & 0.395 & -0.142 & 0.000 \\
\hline Contract contingent on sale of securities -- Entrepreneur incentives & 0.125 & 1.108 & -0.021 & 0.033 & -0.157 & 0.000 \\
\hline Contract contingent on financial performance (all) & -0.028 & 0.056 & 0.248 & $4.368^{\star \star}$ & -0.078 & 0.433 \\
\hline Contract contract on non-financial performance (all) & -0.040 & 0.116 & 0.219 & $3.390^{\star}$ & -0.064 & 0.288 \\
\hline Contract contingent on certain actions being taken (all) & 0.166 & 1.968 & -0.029 & 0.058 & -0.210 & 0.000 \\
\hline Contract contingent on sale of securities (all) & 0.218 & $3.379^{*}$ & -0.069 & 0.340 & -0.222 & 0.000 \\
\hline VC has veto over asset sales & -0.100 & 0.704 & 0.171 & 2.075 & -0.016 & 0.017 \\
\hline $\mathrm{VC}$ has veto over asset purchases & -0.054 & 0.210 & 0.170 & 2.046 & -0.059 & 0.251 \\
\hline VC has veto over changes in control & -0.145 & 1.500 & 0.266 & $5.021^{\star \star}$ & -0.077 & 0.419 \\
\hline VC has veto over issuance of equity & -0.122 & 1.055 & 0.200 & $2.832^{\star \star}$ & -0.010 & 0.008 \\
\hline VC has veto over other decisions & -0.057 & 0.229 & 0.139 & 1.379 & -0.010 & 0.008 \\
\hline VC ownership percentage $>50 \%$ & 0.016 & 0.019 & 0.155 & 1.703 & -0.020 & 0.029 \\
\hline VC ownership percentage $<50 \%$ & -0.016 & 0.019 & -0.155 & 1.703 & 0.020 & 0.029 \\
\hline VC ownership percentage increases if bad performance & 0.122 & 1.055 & -0.079 & 0.444 & 0.158 & 1.769 \\
\hline VC's Board Seats / Total Board Seats $>50 \%$ & -0.123 & 1.073 & 0.206 & $3.001^{\star}$ & -0.014 & 0.014 \\
\hline VC's Board Seats / Total Board Seats $<50 \%$ & 0.123 & 1.073 & -0.206 & $3.001^{\star}$ & 0.014 & 0.014 \\
\hline VC's board seats increase if bad performance & 0.175 & 2.187 & -0.209 & $3.116^{\star}$ & -0.014 & 0.014 \\
\hline VC has right to replace CEO & -0.099 & 0.690 & 0.194 & $2.680^{*}$ & 0.031 & 0.070 \\
\hline VC shares auutomatically convert upon IPO & -0.072 & 0.370 & 0.185 & 2.438 & -0.093 & 0.620 \\
\hline$V C$ has right of first refusal & -0.078 & 0.431 & 0.169 & 2.038 & -0.026 & 0.049 \\
\hline VC has co-sale agreement & -0.030 & 0.062 & 0.171 & 2.075 & -0.095 & 0.640 \\
\hline VC has antidilution provision & -0.271 & 5.223 & 0.318 & $7.184^{\star \star \star}$ & 0.020 & 0.029 \\
\hline$V C$ has protection rights against new issues & -0.060 & 0.253 & 0.054 & 0.204 & 0.107 & 0.812 \\
\hline VC has redemption rights & 0.033 & 0.077 & -0.015 & 0.016 & -0.109 & 0.838 \\
\hline VC has information rights in operating plans and financials & -0.077 & 0.416 & 0.289 & $5.929^{\star \star}$ & -0.201 & $2.870^{*}$ \\
\hline VC has demand registration rights & -0.216 & $3.301^{*}$ & 0.367 & $9.586^{* \star \star}$ & 0.051 & 0.186 \\
\hline VC has piggyback registration rights & -0.239 & 0.000 & 0.332 & 0.000 & 0.252 & $4.511^{\star \star}$ \\
\hline VC has control over exit & -0.145 & 1.500 & 0.138 & 1.359 & 0.079 & 0.443 \\
\hline Other syndicated VC has control over exit & 0.125 & 1.108 & -0.225 & $3.578^{\star}$ & 0.091 & 0.586 \\
\hline Founder has control over exit & 0.077 & 0.416 & 0.003 & 0.001 & -0.156 & 1.724 \\
\hline Respondent is Lead VC & 0.160 & 1.811 & 0.070 & 0.347 & -0.201 & $2.870^{\star}$ \\
\hline Syndication & 0.251 & $4.487^{\star \star}$ & -0.380 & $10.261^{\star \star \star}$ & 0.123 & 1.073 \\
\hline Seed & -0.203 & $2.918^{\star}$ & 0.087 & 0.535 & 0.064 & 0.295 \\
\hline Early & 0.050 & 0.176 & -0.069 & 0.340 & -0.031 & 0.068 \\
\hline Expansion & 0.123 & 1.072 & -0.171 & 2.074 & -0.035 & 0.089 \\
\hline Late & 0.233 & $3.840^{\star \star}$ & -0.140 & 1.386 & -0.126 & 0.000 \\
\hline Turnaround & -0.080 & 0.000 & -0.128 & 0.000 & 0.231 & 0.000 \\
\hline Buyout & -0.110 & 0.866 & 0.283 & $5.703^{\star \star}$ & 0.016 & 0.017 \\
\hline High-Tech & 0.004 & 0.001 & -0.122 & 1.060 & -0.036 & 0.094 \\
\hline Medical/Biotech & -0.046 & 0.151 & -0.025 & 0.045 & 0.034 & 0.081 \\
\hline Electronic/Computer & 0.050 & 0.179 & -0.025 & 0.045 & -0.075 & 0.403 \\
\hline Communication/Internet & 0.001 & 0.000 & -0.087 & 0.542 & -0.009 & 0.006 \\
\hline
\end{tabular}


Table 4. Correlations Across Explanatory Variables

This table presents correlation coefficients across explanatory variables used in regressions in subsequent tables. Correlation coefficients that are significant at the $5 \%$ level of significance are

\begin{tabular}{|c|c|c|c|c|c|c|c|c|c|c|c|c|c|c|c|c|c|c|}
\hline & $\begin{array}{l}\mathbf{\Xi} \\
\mathbb{\Phi} \\
\oplus \\
\end{array}$ & $\begin{array}{l}\text { 餏 } \\
\text { W }\end{array}$ & 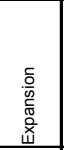 & 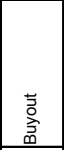 & 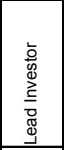 & 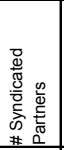 & 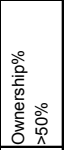 & 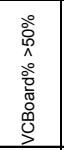 & 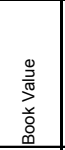 & 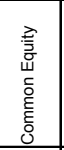 & 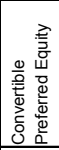 & 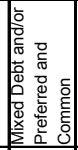 & 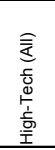 & 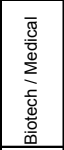 & 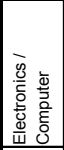 & 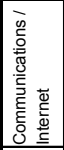 & 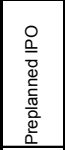 & 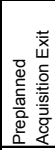 \\
\hline Seed & 1.000 & & & & & & & & & & & & & & & & & \\
\hline Early & \begin{tabular}{|l|}
-0.195 \\
\end{tabular} & 1.000 & & & & & & & & & & & & & & & & \\
\hline Expansion & -0.267 & -0.352 & 1.000 & & & & & & & & & & & & & & & \\
\hline Buyout & -0.244 & -0.322 & -0.442 & 1.000 & & & & & & & & & & & & & & \\
\hline Lead Investor & 0.016 & 0.251 & -0.126 & -0.166 & 1.000 & & & & & & & & & & & & & \\
\hline \# Syndicated Partners & -0.196 & -0.401 & 0.140 & 0.328 & -0.400 & 1.000 & & & & & & & & & & & & \\
\hline Ownership $\%>50 \%$ & 0.022 & -0.352 & -0.138 & 0.415 & -0.263 & 0.327 & 1.000 & & & & & & & & & & & \\
\hline VCBoard $\%>50 \%$ & 0.142 & -0.221 & 0.007 & 0.044 & -0.170 & 0.251 & 0.449 & 1.000 & & & & & & & & & & \\
\hline Book Value & -0.164 & -0.188 & -0.085 & 0.380 & 0.196 & 0.136 & 0.122 & 0.036 & 1.000 & & & & & & & & & \\
\hline Common Equity & -0.107 & 0.013 & 0.210 & -0.183 & \begin{tabular}{|l|}
0.104 \\
\end{tabular} & -0.097 & \begin{tabular}{|c|}
-0.084 \\
\end{tabular} & -0.045 & 0.003 & 1.000 & & & & & & & & \\
\hline Convertible Preferred Equity & 0.229 & 0.248 & -0.076 & \begin{tabular}{|l|}
-0.256 \\
\end{tabular} & 0.086 & -0.227 & $\mid-0.286$ & -0.044 & -0.123 & -0.411 & 1.000 & & & & & & & \\
\hline Mixed Debt and/or Preferred and Common & 0.161 & -0.175 & 0.181 & -0.165 & -0.085 & 0.028 & 0.128 & 0.187 & \begin{tabular}{|l|}
-0.135 \\
\end{tabular} & -0.300 & -0.162 & 1.000 & & & & & & \\
\hline High-Tech & 0.274 & 0.346 & 0.019 & -0.424 & 0.164 & -0.374 & -0.276 & -0.059 & \begin{tabular}{|l|}
-0.253 \\
\end{tabular} & 0.072 & 0.232 & -0.014 & 1.000 & & & & & \\
\hline Biotech / Medical & -0.099 & 0.205 & 0.112 & -0.175 & \begin{tabular}{|l|l|}
0.128 \\
\end{tabular} & -0.146 & \begin{tabular}{|c|}
-0.113 \\
\end{tabular} & -0.011 & -0.072 & 0.143 & -0.035 & -0.146 & 0.352 & 1.000 & & & & \\
\hline Electronics / Computer & 0.053 & 0.102 & -0.076 & -0.039 & 0.110 & -0.181 & -0.076 & -0.151 & -0.064 & 0.065 & -0.069 & -0.035 & 0.392 & -0.199 & 1.000 & & & \\
\hline Communications / Internet & 0.342 & 0.131 & -0.003 & -0.298 & -0.018 & -0.140 & -0.151 & 0.075 & \begin{tabular}{|l|}
-0.169 \\
\end{tabular} & -0.094 & 0.351 & 0.135 & 0.490 & -0.249 & -0.278 & 1.000 & & \\
\hline Preplanned IPO & -0.074 & -0.073 & 0.138 & -0.082 & 0.124 & 0.107 & -0.060 & -0.098 & 0.249 & 0.145 & 0.005 & -0.053 & 0.026 & -0.092 & -0.175 & 0.259 & 1.000 & \\
\hline $\begin{array}{l}\text { Preplanned Acquisition Exit } \\
\text { Pro }\end{array}$ & 0.115 & -0.096 & -0.068 & 0.094 & -0.053 & 0.146 & 0.202 & 0.160 & -0.008 & -0.181 & 0.119 & -0.011 & -0.027 & -0.128 & -0.115 & 0.177 & -0.201 & 1.000 \\
\hline
\end{tabular}

Table 5a. Determinants of Security Choice

\begin{tabular}{|c|c|c|c|c|c|c|c|c|}
\hline \multirow[b]{3}{*}{ Explanatory Variables } & \multicolumn{8}{|c|}{$\begin{array}{c}\text { Binomial Logit Model Dependent Variables } \\
\end{array}$} \\
\hline & \multicolumn{2}{|c|}{ Common Equity } & \multicolumn{2}{|c|}{ Convertible Preferred Equity } & \multicolumn{2}{|c|}{ Mixed Preferred and Common } & \multicolumn{2}{|c|}{ Mixed Debt and/or Preferred and Common } \\
\hline & Coefficient & t-statistic & Coefficient & t-statistic & Coefficient & t-statistic & Coefficient & t-statistic \\
\hline Investor Fixed Effects? & \multicolumn{2}{|c|}{ Yes } & \multicolumn{2}{|c|}{ Yes } & \multicolumn{2}{|c|}{ Yes } & \multicolumn{2}{|c|}{ Yes } \\
\hline Seed & -1.2534 & -1.1927 & 2.4459 & 1.4281 & -1.9957 & -1.3867 & -0.2368 & -0.2084 \\
\hline Early & -0.9651 & -1.1451 & 4.2387 & $2.5691^{1 *}$ & -1.9945 & -1.6258 & NA & NA \\
\hline Expansion & -0.7211 & -1.0923 & 2.7785 & $1.9928^{* *}$ & -2.1944 & $-2.1816^{\text {t* }}$ & 2.4139 & $1.9832^{2 *}$ \\
\hline Book Value & -0.00001 & -0.3850 & 0.000004 & 0.0670 & 0.00004 & 1.4555 & -0.0006 & $-2.3414^{* *}$ \\
\hline Lead Investor & 0.4228 & 0.6581 & -4.6260 & $-3.6680^{0 * * *}$ & -2.3751 & $-2.1754^{* *}$ & -1.7702 & $-1.8840^{*}$ \\
\hline \# Syndicated Investors & 0.1042 & 0.3083 & -1.2919 & $-2.2698^{* * t}$ & -0.3882 & -0.8542 & -1.6687 & $-2.0415^{\text {t*t}}$ \\
\hline Preplanned IPO & 1.1900 & 1.3296 & -0.4261 & -0.3311 & -1.4170 & -1.0929 & -2.6401 & -1.4366 \\
\hline Preplanned Acquisition & -0.7124 & -1.0705 & -0.3350 & -0.3363 & -0.4399 & -0.5375 & -1.4318 & -1.0621 \\
\hline Medical / Biotech & -1.4120 & -1.6206 & 1.2966 & 1.0400 & 1.0536 & 0.9128 & NA & NA \\
\hline Electronics / Computer & 0.1543 & 0.2082 & -1.5754 & -1.2183 & -1.2407 & -1.5323 & -0.3238 & -0.2616 \\
\hline \multirow[t]{2}{*}{ Communications / Internet } & -1.7885 & $-2.1578^{* *}$ & -2.8698 & -1.6315 & 0.3741 & 0.3179 & -0.4259 & -0.3301 \\
\hline & \multicolumn{2}{|c|}{ Predicted Outcomes } & \multicolumn{2}{|c|}{ Predicted Outcomes } & \multicolumn{2}{|c|}{ Predicted Outcomes } & \multicolumn{2}{|c|}{ Predicted Outcomes } \\
\hline Actual Outcomes & No & Yes & No & Yes & No & Yes & No & Yes \\
\hline No & 61 & 14 & 101 & 7 & 90 & 12 & 115 & 3 \\
\hline Yes & 17 & 40 & 10 & 4 & 14 & 16 & 8 & 6 \\
\hline
\end{tabular}


Table 5b (part 1). Determinants of Security Choice

This table presents multinomial logit estimates of the determinants of the selected security choice based on entrepreneurial firm characteristics, VC fund characteristics, the book value of the investment, whether the VC was lead investor, the number of syndicated partners, and the VC's board seats. ${ }^{*}, * *, * * *$ Significant at the $10 \%, 5 \%$ and $1 \%$ levels, respectively.

\begin{tabular}{|c|c|c|c|c|c|c|}
\hline \multirow[b]{3}{*}{ Explanatory Variables } & \multicolumn{6}{|c|}{ Multinomial Logit Model Dependent Variables } \\
\hline & \multicolumn{2}{|c|}{$\log _{\mathrm{e}}\left(\mathrm{P}_{\text {Common }} / \mathrm{P}_{\text {ConvertiblePreferred }}\right)$} & \multicolumn{2}{|c|}{$\log _{\mathrm{e}}\left(\mathbf{P}_{\text {Common }} / \mathbf{P}_{\text {MixedPred-Common }}\right)$} & \multicolumn{2}{|c|}{$\log _{\mathrm{e}}\left(\mathbf{P}_{\text {Common }} / \mathbf{P}_{\text {MixedDebt-Pref-Common }}\right)$} \\
\hline & Coefficient & t-statistic & Coefficient & t-statistic & Coefficient & t-statistic \\
\hline Constant & 2.8608 & $1.9217^{*}$ & 1.4485 & 1.2581 & -0.0376 & -0.0343 \\
\hline Seed & -2.9248 & $-1.9623^{\star *}$ & 0.6067 & 0.4374 & 0.3127 & 0.3096 \\
\hline Early & -2.8634 & $-1.9903^{\star *}$ & 0.4887 & 0.4977 & 1.4334 & 1.3999 \\
\hline Expansion & -1.4325 & -1.1165 & 1.5712 & $2.1034^{\star *}$ & 1.0524 & $1.6601^{* *}$ \\
\hline Book Value & -0.00002 & -0.5168 & -0.00002 & -0.7950 & 0.00005 & 1.0870 \\
\hline Lead Investor & 0.2479 & 0.3457 & -1.2327 & -1.2636 & -0.7969 & -0.9177 \\
\hline \# Syndicated Investors & 0.1017 & 0.2816 & 0.1057 & 0.2865 & 0.3303 & 0.7940 \\
\hline Preplanned IPO & 0.2915 & 0.3100 & 0.8101 & 0.7390 & 1.7977 & 1.4996 \\
\hline Preplanned Acquisition & -1.0148 & -1.3975 & -0.8458 & -1.2468 & 0.0446 & 0.0652 \\
\hline Medical / Biotech & 0.6955 & 0.7081 & -0.3625 & -0.4225 & 1.3947 & 1.2022 \\
\hline Electronics / Computer & 0.8826 & 0.8817 & 0.2525 & 0.2985 & 0.0380 & 0.0545 \\
\hline \multirow[t]{2}{*}{ Communications / Internet } & -0.6443 & -0.7484 & 0.4684 & 0.4377 & -0.4032 & -0.4896 \\
\hline & \multicolumn{4}{|c|}{ Predicted Outcomes } & & \\
\hline Actual Outcomes & Common & Conv. Preferred & Mixed Pref+Com & Mixed Debt+Com & & \\
\hline Common & 42 & 6 & 2 & 7 & & \\
\hline Convertible Preferred & 11 & 11 & 1 & 1 & & \\
\hline Mixed Pref + Common & 8 & 0 & 7 & 8 & & \\
\hline Mixed Debt + Common & 13 & 3 & 5 & 7 & Table co & below... \\
\hline
\end{tabular}

Table 5b (part 2). Determinants of Security Choice

This table presents multinomial logit estimates of the determinants of the selected security choice based on entrepreneurial firm characteristics, VC fund characteristics, the book value of the investment, whether the VC was lead investor, the number of syndicated partners, and the VC's board seats. ${ }^{*}, * *, * * *$ Significant at the $10 \%, 5 \%$ and

\begin{tabular}{|c|c|c|c|c|c|c|}
\hline \multirow[b]{3}{*}{ Explanatory Variables } & \multicolumn{6}{|c|}{ Multinomial Logit Model Dependent Variables } \\
\hline & \multicolumn{2}{|c|}{$\log _{\mathrm{e}}\left(\mathrm{P}_{\text {Convertible Preferred }} / \mathrm{P}_{\text {MixedPref-Common }}\right)$} & \multicolumn{2}{|c|}{$\log _{\mathrm{e}}\left(\mathrm{P}_{\text {Convertible Preferred }} / \mathrm{P}_{\text {MixedDebt-Pref-Common }}\right)$} & \multicolumn{2}{|c|}{$\log _{\mathrm{e}}\left(\mathrm{P}_{\text {MixedPref-Common }} / \mathrm{P}_{\text {MixedDebt-Pref-Common }}\right)$} \\
\hline & Coefficient & t-statistic & Coefficient & t-statistic & Coefficient & t-statistic \\
\hline Constant & -1.4123 & -0.8133 & -2.8985 & -1.7119 & -1.4862 & -1.0627 \\
\hline Seed & 3.5315 & $1.9251^{*}$ & 3.2376 & $2.0613^{\star *}$ & -0.2940 & -0.2019 \\
\hline Early & 3.3521 & $2.1064^{* *}$ & 4.2968 & $2.6613^{* * *}$ & 0.9447 & 0.7766 \\
\hline Expansion & 3.0037 & $2.1689^{* *}$ & 2.4849 & $1.8633^{*}$ & -0.5188 & -0.6309 \\
\hline Book Value & 0.000002 & 0.0481 & 0.0001 & 1.2214 & 0.0001 & 1.4533 \\
\hline Lead Investor & -1.4805 & -1.3539 & -1.0448 & -1.0642 & 0.4357 & 0.3643 \\
\hline \# Syndicated Investors & 0.0040 & 0.0087 & 0.2286 & 0.4632 & 0.2247 & 0.4767 \\
\hline Preplanned IPO & 0.5186 & 0.3852 & 1.5061 & 1.0887 & 0.9876 & 0.6619 \\
\hline Preplanned Acquisition & 0.1689 & 0.1990 & 1.0593 & 1.3094 & 0.8904 & 1.1998 \\
\hline Medical / Biotech & -1.0581 & -0.8953 & 0.6992 & 0.4945 & 1.7573 & 1.3715 \\
\hline Electronics / Computer & -0.6300 & -0.5256 & -0.8445 & -0.7662 & -0.2145 & -0.2370 \\
\hline Communications / Internet & 1.1127 & 0.9083 & 0.2411 & 0.2405 & -0.8716 & -0.7556 \\
\hline
\end{tabular}




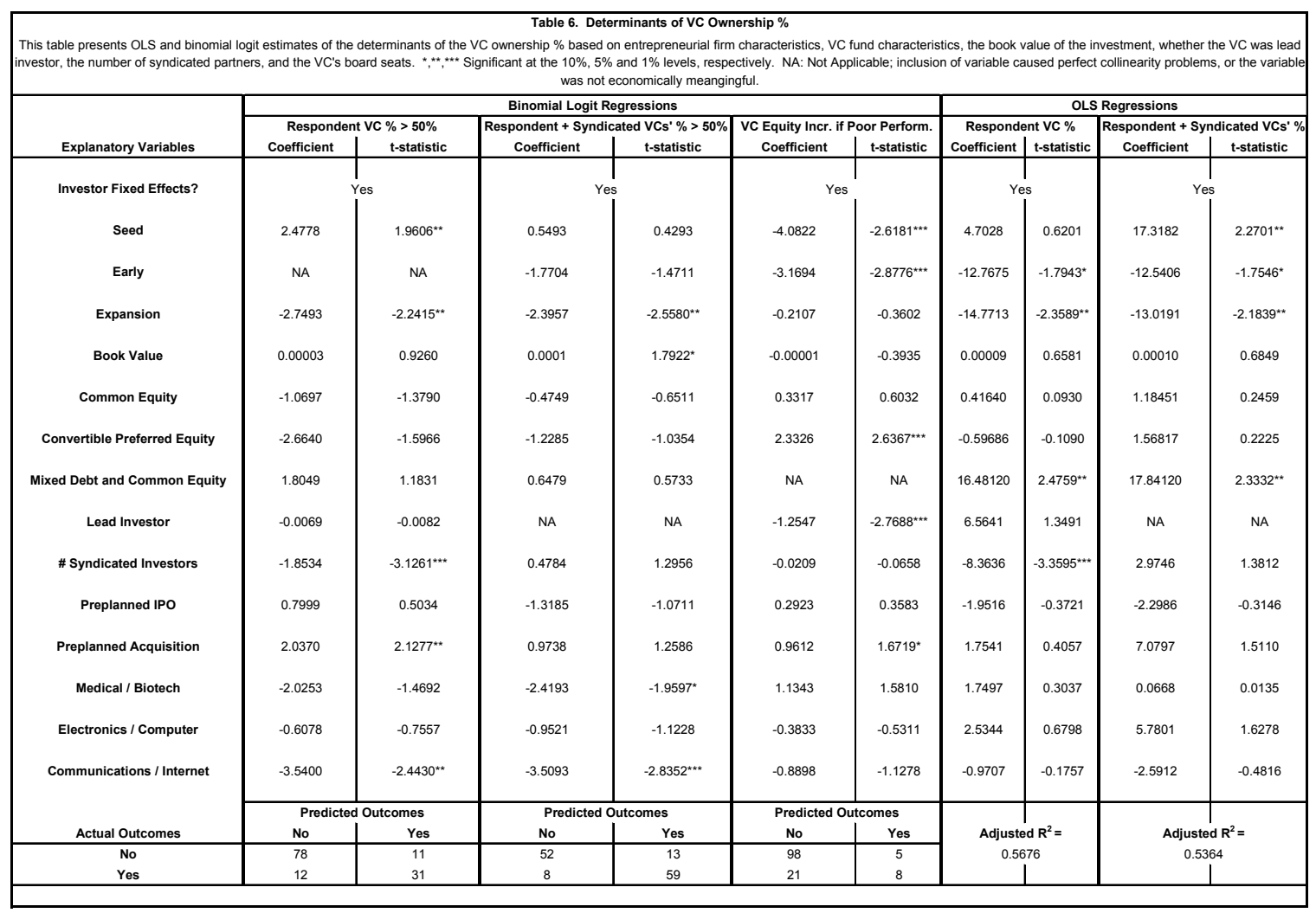




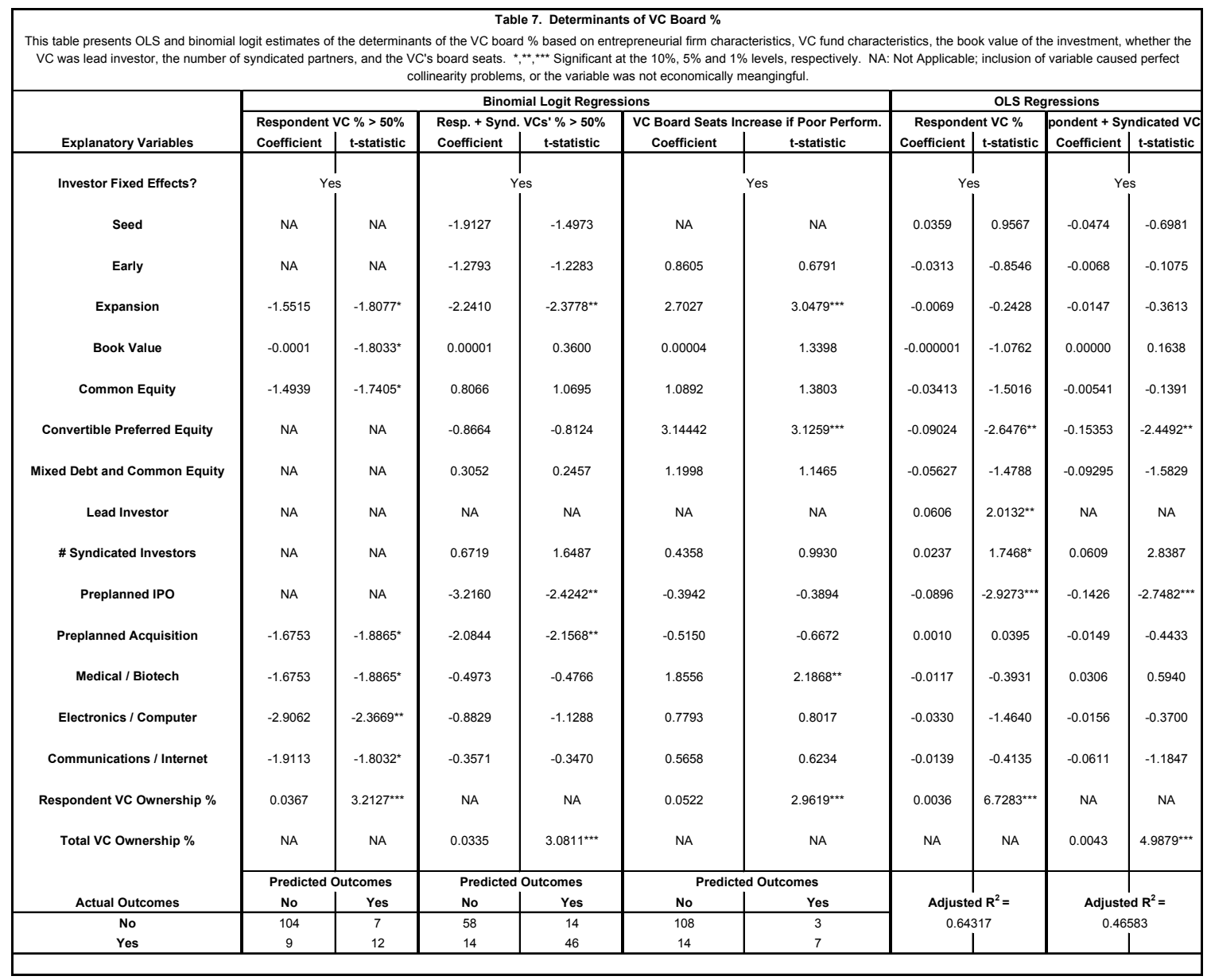




\begin{tabular}{|c|c|c|c|c|c|c|c|c|c|c|c|c|c|c|c|c|}
\hline \multirow{5}{*}{$\begin{array}{c}\text { This table presents regressions for } \\
\text { Explanatory Variables } \\
\end{array}$} & \multirow{2}{*}{\multicolumn{16}{|c|}{$\begin{array}{l}\text { s of contingencies in venture capital contracts that directly affect either the entrepreneur or the venture capitalist. }{ }^{*}, * * \text {, } * * \text { Significant at the } 10 \%, 5 \%, \text { and } 1 \% \text { levels, respectively. NA: Not } \\
\text { Applicable; inclusion of variable caused perfect collinearity problems. } \\
\text { Dependent Variables }\end{array}$}} \\
\hline & & & & & & & & & & & & & & & & \\
\hline & \multirow{3}{*}{\multicolumn{2}{|c|}{\begin{tabular}{|l|l|}
\multicolumn{3}{|c|}{} \\
\multicolumn{2}{|c|}{ Financial Performance } \\
Coeficient & t-statistic \\
\end{tabular}}} & & \multicolumn{8}{|c|}{$\begin{array}{ll}\text { Venture Capitalist's Contingencies (Incentives): }\end{array}$} \\
\hline & & & \multicolumn{6}{|c|}{ Entrepreneurs' Contingencies (Incentives): } & \multicolumn{2}{|c|}{ Financial Performance } & \multicolumn{2}{|c|}{ Non-Financial Performance } & \multirow{2}{*}{\multicolumn{2}{|c|}{$\begin{array}{l}\text { Certain Actions } \\
\text { Coeficient|t-statistic }\end{array}$}} & \multicolumn{2}{|c|}{ Sale of Equity } \\
\hline & & & Coeficient & t-statistic & Coeficient & t-statistic & Coeficient & \begin{tabular}{|l|l|l} 
t-statistic \\
\end{tabular} & Coeficient & t-statistic & Coeficient & t-statistic & & & Coeficient & t-statistic \\
\hline Fixed Effect VC Fund Dummies & \multicolumn{2}{|c|}{ Yes } & \multicolumn{2}{|c|}{ Yes } & \multicolumn{2}{|c|}{ Yes } & \multicolumn{2}{|c|}{ Yes } & \multicolumn{2}{|c|}{ Yes } & \multicolumn{2}{|c|}{ Yes } & \multicolumn{2}{|c|}{ Yes } & \\
\hline Seed & -1.3181 & -1.0600 & NA & NA & NA & NA & NA & NA & 1.7762 & 0.9692 & 0.3201 & 0.1738 & NA & NA & NA & NA \\
\hline Early & 0.3798 & 0.4651 & 0.4319 & 0.5559 & 0.3058 & 0.4051 & NA & NA & 1.5336 & 0.8931 & -1.9451 & -0.9802 & -2.3730 & -1.1723 & -0.2880 & -0.2962 \\
\hline Expansion & -0.2060 & -0.2884 & 0.1558 & 0.1867 & -0.3617 & -0.4714 & -1.2119 & -1.0534 & 1.4588 & 0.7963 & -0.4638 & -0.2662 & -1.7333 & -0.9062 & -1.1524 & -1.2294 \\
\hline Lead Investor & NA & NA & $\mathrm{NA}$ & NA & NA & NA & NA & NA & -3.6570 & $-2.2949^{* *}$ & -3.4084 & $-2.8569^{* * *}$ & -2.9811 & $-1.8074^{*}$ & 0.0689 & 0.1076 \\
\hline \# Syndicated Investors & 0.1210 & 0.3805 & -0.1260 & -0.3292 & -0.1713 & -0.4354 & -0.8542 & -1.2395 & -2.1949 & $-2.3444^{* *}$ & -1.6069 & $-1.9191^{*}$ & -1.0999 & -1.1815 & -0.9716 & $-1.9144^{*}$ \\
\hline vc Owner $\%>50 \%$ & -0.9423 & -1.6162 & -2.3330 & $-2.7081^{\star \star \star}$ & -1.3033 & $-1.9563^{*}$ & -0.9273 & -1.1676 & 1.0284 & 0.8449 & -2.8225 & $-1.6624^{*}$ & -0.8501 & -0.4868 & -1.3910 & -1.6433 \\
\hline Book Value & 0.0001 & 1.5303 & -0.0002 & $-1.8555^{*}$ & -0.0001 & $-1.7630^{*}$ & -0.0001 & -1.2335 & -0.0001 & -0.9304 & -0.0001 & -0.5607 & -0.0006 & -1.0988 & -0.00002 & -0.7187 \\
\hline Common Equity & -0.9172 & -1.4281 & -0.7697 & -1.0116 & -0.5932 & -0.8241 & -4.3338 & $-2.2280^{* *}$ & -3.6972 & $-1.6529^{*}$ & -1.0217 & -0.5649 & -6.4843 & $-1.8872^{\star}$ & $|-1.7911|$ & $-1.8658^{*}$ \\
\hline Convertible Preferred Equity & 2.0970 & $1.7860^{*}$ & -0.7206 & -0.7516 & -1.1408 & -1.1268 & NA & NA & 3.1596 & $1.9794^{* *}$ & -1.6506 & -0.7802 & -3.7396 & -0.9970 & 2.6864 & $2.9040^{* * * t}$ \\
\hline Mixed Debt and Common & 0.5073 & 0.5432 & -0.4088 & -0.3704 & -1.3021 & -0.9475 & NA & NA & 1.9294 & 0.9982 & 1.9898 & 1.0829 & -3.0522 & -0.8237 & NA & NA \\
\hline Biotech / Medical & -0.4758 & -0.6203 & 1.6033 & $1.7087^{*}$ & 1.4239 & 1.6266 & -2.0079 & -1.5589 & -1.3864 & -0.9888 & 1.3116 & 0.7352 & 1.2290 & 0.5392 & -0.2897 & -0.2644 \\
\hline Computer / Electronics & -1.4802 & $-1.8221^{*}$ & -0.3820 & -0.4423 & -1.0678 & -1.1659 & -30.1400 & -0.00003 & -0.7363 & -0.6070 & 0.7249 & 0.4326 & NA & NA & -2.0828 & $-1.6558^{*}$ \\
\hline Communication / Internet & -1.4071 & -1.5017 & 0.0999 & 0.1098 & 0.8116 & 0.8511 & -4.8427 & $-2.8322^{2+*+1}$ & -2.5193 & -1.5243 & -0.4714 & -0.3127 & 1.0043 & 0.4046 & -1.6455 & -1.4388 \\
\hline Preplanned IPO & -1.4614 & -1.4017 & -0.5114 & -0.4987 & 0.4550 & 0.4840 & 4.0103 & $2.0099^{* *}$ & 0.5079 & 0.3559 & 3.9198 & $2.3332^{* *}$ & 8.5758 & $2.1290^{+*}$ & 3.2821 & $2.3514^{* *}$ \\
\hline \multirow[t]{2}{*}{ Preplanned Acquisition } & -0.2090 & -0.3039 & -0.3540 & -0.4285 & -1.0413 & -1.1201 & 0.6505 & 0.5626 & 0.2603 & 0.2780 & 3.6202 & $2.5493^{* \star}$ & 5.2542 & 1.5778 & -1.0465 & -0.9735 \\
\hline & \multicolumn{8}{|c|}{ Predicted Outcomes } & \multicolumn{8}{|c|}{$\frac{1}{\text { Predicted Outcomes }}$} \\
\hline Actual Outcomes & No & Yes & No & Yes & No & Yes & No & Yes & No & Yes & No & Yes & No & Yes & No & Yes \\
\hline No & 89 & 8 & 101 & 8 & 108 & 4 & 120 & 1 & 101 & 8 & 115 & 4 & 121 & 2 & 110 & 4 \\
\hline Yes & 19 & 16 & 13 & 10 & 14 & 6 & 6 & 5 & 9 & 13 & 4 & 9 & 2 & 7 & 11 & 7 \\
\hline
\end{tabular}


Table 9. Determinants of Veto Rights

\begin{tabular}{|c|c|c|c|c|c|c|c|c|c|c|}
\hline \multirow[b]{3}{*}{ Explanatory Variables } & \multicolumn{10}{|c|}{ Dependent Variables: Veto Rights } \\
\hline & \multicolumn{2}{|c|}{ Asset Sales } & \multicolumn{2}{|c|}{ Asset Purchases } & \multicolumn{2}{|c|}{ Changes in Control } & \multicolumn{2}{|c|}{ Issuances of Equity } & \multicolumn{2}{|c|}{ Other } \\
\hline & Coefficient & t-statistic & Coefficient & t-statistic & Coefficient & t-statistic & Coefficient & t-statistic & Coefficient & t-statistic \\
\hline VC Fund Fixed Effects Dummies? & \multicolumn{2}{|c|}{ Yes } & \multicolumn{2}{|c|}{ Yes } & \multicolumn{2}{|c|}{ Yes } & \multicolumn{2}{|c|}{ Yes } & \multicolumn{2}{|c|}{ Yes } \\
\hline Seed & NA & NA & NA & NA & NA & NA & NA & NA & 3.7236 & $2.1415^{\star *}$ \\
\hline Early & -1.4519 & -1.5649 & -2.0208 & $-2.4372^{\star \star}$ & 0.0065 & 0.0080 & -0.5983 & -0.7661 & 2.0843 & $1.8447^{*}$ \\
\hline Expansion & -0.8521 & -1.0999 & -0.9039 & -1.2284 & -0.9968 & -1.4299 & -0.8390 & -1.1713 & -0.6916 & -0.9379 \\
\hline \# Syndicated Investors & 0.4360 & 0.9739 & 0.2776 & 0.7142 & 0.0047 & 0.0135 & -0.0250 & -0.0730 & -0.0151 & -0.0403 \\
\hline Lead VC & 2.7342 & $3.8964^{\star \star \star}$ & 2.3116 & $3.8304^{\star \star \star}$ & 1.4707 & $2.9587^{\star \star \star}$ & 0.9842 & $2.1464^{\star \star}$ & 1.8776 & $3.3563^{\star * *}$ \\
\hline VC Board >50\% & 1.2051 & $1.7610^{*}$ & 0.8036 & 1.3208 & 0.4304 & 0.7640 & 0.7148 & 1.2516 & -0.0890 & -0.1528 \\
\hline Book Value & -0.00004 & -1.3195 & -0.00002 & -0.7164 & 0.00000 & 0.1415 & 0.00000 & 0.0986 & -0.0001 & $-2.5037^{\star *}$ \\
\hline Common Equity & -2.9845 & $-3.3445^{\star \star \star}$ & -2.2749 & $-2.9325^{\star \star \star}$ & -1.1585 & $-1.7069^{\star}$ & -1.3267 & $-1.9406^{*}$ & -0.8744 & -1.2636 \\
\hline Convertible Preferred Equity & 2.3312 & $1.9205^{\star}$ & 1.7826 & $1.6993^{*}$ & 2.0764 & 1.6491 & 2.5212 & $1.8966^{*}$ & -2.7755 & $-2.5806^{\star \star}$ \\
\hline Debt and Common & -1.3250 & -1.1301 & -1.0170 & -0.9740 & 0.1209 & 0.1176 & 0.5253 & 0.4902 & -3.1940 & $-2.4343^{\star \star}$ \\
\hline Biotech / Medical & -0.8132 & -0.9196 & 0.0808 & 0.0956 & 1.7816 & $2.0475^{\star \star}$ & 2.6244 & $2.6184^{\star \star \star}$ & 2.0095 & $2.2129^{\star \star}$ \\
\hline Computer / Electronic & 1.7764 & $1.9577^{\star}$ & 1.5232 & $1.8861^{*}$ & 1.7260 & $2.1512^{\star \star}$ & 2.1988 & $2.5968^{\star \star \star}$ & 1.7321 & $2.0509^{\star \star}$ \\
\hline Communications / Internet & -0.9829 & -0.9354 & -0.2429 & -0.2509 & 0.5550 & 0.6247 & 0.8772 & 0.9820 & -1.6131 & -1.6486 \\
\hline Preplanned IPO & 0.8854 & 0.8363 & 0.2737 & 0.2930 & -0.0023 & -0.0026 & -0.1557 & -0.1872 & 1.5451 & 1.6041 \\
\hline \multirow[t]{2}{*}{ Preplanned Acquisition } & 1.4511 & 1.5025 & 1.1798 & 1.3632 & 1.3437 & 1.5280 & 1.0194 & 1.2934 & 2.5296 & $2.8557^{\star \star *}$ \\
\hline & \multicolumn{10}{|c|}{ Predicted Outcomes } \\
\hline Actual Outcomes & No & Yes & No & Yes & No & Yes & No & Yes & No & Yes \\
\hline No & 31 & 13 & 31 & 15 & 20 & 15 & 26 & 13 & 32 & 14 \\
\hline Yes & 9 & 79 & 9 & 77 & 9 & 88 & 8 & 85 & 12 & 74 \\
\hline
\end{tabular}


Table 10 (part 1). Determinants of Control Rights (see Appendix B)

This table presents the determinants of VC control rights by type of right, depending on the characteristics of the entrepreneurial. * ${ }^{* *}$, ${ }^{* * *}$ Significant at the $10 \%, 5 \%$, and $1 \%$ levels, respectively. NA: Not Applicable; inclusion of variable caused perfect collinearity problems.

\begin{tabular}{|c|c|c|c|c|c|c|c|c|c|c|}
\hline \multirow[b]{3}{*}{ Explanatory Variables } & \multicolumn{10}{|c|}{ Dependent Variables: Control Rights } \\
\hline & \multicolumn{2}{|c|}{ Replace CEO } & \multicolumn{2}{|c|}{ Automatic Convert IPO } & \multicolumn{2}{|c|}{ First Refusal in Sale } & \multicolumn{2}{|c|}{ Co-Sale Agreement } & \multicolumn{2}{|c|}{ Anti-Dilution } \\
\hline & Coefficient & | t-statistic & Coefficient & t-statistic & Coefficient & | t-statistic & Coefficient & t-statistic & Coefficient & t-statistic \\
\hline VC Fund Fixed Effects Dummies? & \multicolumn{2}{|c|}{ Yes } & \multicolumn{2}{|c|}{ Yes } & \multicolumn{2}{|c|}{ Yes } & \multicolumn{2}{|c|}{ Yes } & \multicolumn{2}{|c|}{ Yes } \\
\hline Seed & -1.4088 & -1.0572 & NA & NA & -1.2391 & -1.0805 & 0.5820 & 0.5278 & 1.7293 & 1.3436 \\
\hline Early & -35.6262 & -0.00002 & -2.4794 & $-2.0477^{\star \star}$ & -2.3249 & $-2.3616^{* \star}$ & -0.9357 & -1.0125 & -1.1243 & -1.2276 \\
\hline Expansion & -1.5823 & $-1.7803^{*}$ & -3.2323 & $-3.0773^{\star \star \star}$ & 0.7777 & 1.0814 & -0.4498 & -0.5944 & -0.6809 & -0.8201 \\
\hline \# Syndicated Investors & 0.6660 & 1.2789 & NA & NA & -0.4660 & -1.2098 & 0.2939 & 0.8345 & 0.4677 & 1.1963 \\
\hline Lead Investor & 1.7628 & $2.7006^{* \star *}$ & -0.8860 & $-1.9103^{*}$ & -1.4431 & $-2.9015^{\star \star \star}$ & 2.4010 & $3.7591^{* \star *}$ & 2.4972 & $3.8687^{\star \star \star}$ \\
\hline VC Board > 50\% & 2.7705 & $2.7147^{\star \star \star \star}$ & -2.2031 & $-2.4594^{\star \star}$ & 2.3422 & $3.8745^{\star \star \star}$ & 0.8490 & 1.4674 & 0.1024 & 0.1691 \\
\hline Book Value & 0.00001 & 0.2096 & -0.00004 & -1.3529 & 0.00003 & 1.0915 & 0.00004 & 0.9493 & -0.0001 & $-1.8790^{*}$ \\
\hline Common Equity & -4.0322 & $-3.0648^{\star \star \star x}$ & NA & NA & 0.1505 & 0.2292 & -2.2676 & $-2.7693^{* \star \star}$ & -2.0771 & $-2.5478^{\star \star}$ \\
\hline Convertible Preferred Equity & -3.0086 & $-2.1365^{\star \star}$ & NA & NA & 3.4173 & $2.9784^{\star \star \star}$ & -2.8961 & $-2.5704^{\star \star}$ & -2.3090 & $-2.1204^{\star \star}$ \\
\hline Mixed Debt and Common & -3.9444 & $-2.7411^{\star \star \star}$ & NA & NA & -0.3566 & -0.3739 & -2.8631 & $-2.5367^{\star \star}$ & -3.4907 & $-2.6722^{\star \star \star}$ \\
\hline Biotech / Medical & 3.0689 & $2.3639^{\star *}$ & NA & NA & -0.8543 & -1.1123 & -1.3159 & -1.5422 & 0.8202 & 0.9579 \\
\hline Computer / Electronics & -0.5499 & -0.5847 & NA & NA & -0.8453 & -1.1604 & 0.8078 & 1.0484 & 1.8571 & $2.2498^{\star *}$ \\
\hline Communications / Internet & -3.4545 & $-2.4577^{\star \star}$ & NA & NA & -0.9059 & -1.0418 & -2.4904 & $-2.1865^{\star \star}$ & -1.8033 & -1.5926 \\
\hline Preplanned IPO & 1.2741 & 0.8823 & 0.8615 & 0.7288 & -0.2845 & -0.3044 & 0.2672 & 0.2562 & 0.9645 & 1.0075 \\
\hline \multirow[t]{2}{*}{ Preplanned Acquisition } & 3.2065 & $2.4947^{\star \star}$ & -0.3056 & -0.3703 & 1.3473 & $1.9229^{*}$ & 2.4006 & $2.3497^{\star *}$ & 4.0928 & $3.2566^{\star \star \star}$ \\
\hline & \multicolumn{10}{|c|}{ Predicted Outcomes } \\
\hline Actual Outcomes & No & Yes & No & Yes & No & Yes & No & Yes & No & Yes \\
\hline No & 71 & 9 & 116 & 5 & 54 & 14 & 33 & 14 & 44 & 13 \\
\hline Yes & 10 & 42 & 5 & 6 & 11 & 53 & 12 & 73 & 7 & 68 \\
\hline
\end{tabular}


Table 10 (part 2). Determinants of Control Rights (see Appendix B)

This table presents the determinants of VC control rights by type of right, depending on the characteristics of the entrepreneurial. *, **, *** Significant at the $10 \%, 5 \%$, and $1 \%$ levels, respectively. NA: Not Applicable; inclusion of variable caused perfect collinearity problems.

\begin{tabular}{|c|c|c|c|c|c|c|c|c|c|c|}
\hline \multirow[b]{3}{*}{ Explanatory Variables } & \multicolumn{10}{|c|}{ Dependent Variables: Control Rights } \\
\hline & \multicolumn{2}{|c|}{ Protection Re New Issues } & \multicolumn{2}{|c|}{ Redemption Rights } & \multicolumn{2}{|c|}{ Information Rights } & \multicolumn{2}{|c|}{ Demand Reg. Rights } & \multicolumn{2}{|c|}{ Piggyback Reg. Rights } \\
\hline & Coefficient & t-statistic & Coefficient & t-statistic & Coefficient & t-statistic & Coefficient & t-statistic & Coefficient & t-statistic \\
\hline VC Fund Fixed Effects Dummies? & \multicolumn{2}{|c|}{ Yes } & \multicolumn{2}{|c|}{ Yes } & \multicolumn{2}{|c|}{ Yes } & \multicolumn{2}{|c|}{ Yes } & \multicolumn{2}{|c|}{ Yes } \\
\hline Seed & -2.4182 & $-1.7422^{*}$ & -2.4096 & $-1.9030^{*}$ & -0.0374 & -0.0292 & -2.9199 & $-2.0980^{* *}$ & NA & NA \\
\hline Early & -1.4674 & -1.4964 & -1.5402 & $-1.7767^{*}$ & -0.6581 & -0.6331 & -3.1071 & $-2.4616^{* *}$ & -1.2207 & -1.2800 \\
\hline Expansion & -0.7197 & -0.9274 & -0.7504 & -1.1098 & 0.3341 & 0.3792 & -2.9800 & $-2.8455^{\star * \star}$ & -3.5227 & $-2.9016^{\star \star *}$ \\
\hline \# Syndicated Investors & -0.5198 & -1.3458 & -0.3762 & -1.0076 & -0.3046 & -0.7274 & -0.2936 & -0.6816 & -1.1671 & $-2.3252^{* * *}$ \\
\hline Lead Investor & 2.8085 & $4.0821^{* * *}$ & 1.8141 & $3.5701^{* * *}$ & 3.4346 & $3.7701^{* * *}$ & 1.2482 & $2.3221^{* *}$ & 1.6856 & $2.7813^{\star * *}$ \\
\hline VC Board > 50\% & 0.9793 & 1.5626 & 0.5753 & 1.0669 & 0.8288 & 1.1900 & 0.1242 & 0.1794 & 0.0526 & 0.0740 \\
\hline Book Value & -0.0001 & $-1.7608^{*}$ & -0.0001 & $-1.9085^{*}$ & 0.00002 & 0.4395 & 0.00004 & 1.1232 & 0.00001 & 0.3022 \\
\hline Common Equity & -2.6887 & $-3.5483^{* * *}$ & -1.5286 & $-2.5364^{* *}$ & -3.7118 & $-3.1920^{* * *}$ & -2.0144 & $-2.5290^{* *}$ & -2.5746 & $-2.8001^{* * *}$ \\
\hline Convertible Preferred Equity & 0.5595 & 0.5177 & -1.8336 & $-1.8942^{*}$ & 0.5089 & 0.3777 & 3.5564 & $3.0199^{* * *}$ & 3.7509 & $3.1273^{* * *}$ \\
\hline Mixed Debt and Common & -3.7202 & $-3.2862^{* * *}$ & -3.6241 & $-2.9220^{* \star \star}$ & -3.2054 & $-2.3920^{* *}$ & 0.8631 & 0.7008 & NA & NA \\
\hline Biotech / Medical & 0.7997 & 0.9117 & 1.2292 & 1.5755 & -0.5163 & -0.5580 & NA & NA & -1.4872 & -1.1949 \\
\hline Computer / Electronics & 2.8754 & $3.0753^{* * *}$ & 1.7070 & $2.1918^{* *}$ & 2.0571 & $1.9901^{* *}$ & -0.3856 & -0.4903 & -0.9999 & -1.2315 \\
\hline Communications / Internet & -1.8383 & $-1.8288^{*}$ & -0.3901 & -0.4363 & -0.9053 & -0.7905 & -2.6918 & $-2.1995^{* *}$ & -6.2615 & $-3.6052^{\star * *}$ \\
\hline Preplanned IPO & 1.6417 & 1.5880 & -0.0853 & -0.0929 & 0.8665 & 0.8037 & -1.2069 & -0.9016 & NA & NA \\
\hline \multirow[t]{2}{*}{ Preplanned Acquisition } & 1.5045 & $1.7551^{*}$ & -0.2928 & -0.4606 & 3.1307 & $2.1319^{* *}$ & -0.1790 & -0.2303 & -0.0934 & -0.1137 \\
\hline & \multicolumn{10}{|c|}{ Predicted Outcomes } \\
\hline Actual Outcomes & No & Yes & No & Yes & No & Yes & No & Yes & No & Yes \\
\hline No & 42 & 11 & 73 & 11 & 31 & 10 & 83 & 7 & 94 & 6 \\
\hline Yes & 11 & 68 & 12 & 36 & 5 & 86 & 9 & 33 & 8 & 24 \\
\hline
\end{tabular}




\begin{tabular}{|c|c|c|c|c|c|c|c|c|c|c|c|c|}
\hline \multirow[b]{2}{*}{ Explanatory Variables } & \multicolumn{6}{|c|}{ Binomial Logit Model Dependent Variables } & \multicolumn{6}{|c|}{ Multinomial Logit Model Dependent Variables } \\
\hline & \multicolumn{2}{|c|}{\begin{tabular}{l|l} 
IPO \\
\end{tabular}} & \multicolumn{2}{|c|}{ Acquisition } & \multicolumn{2}{|c|}{ Write-off } & \multicolumn{2}{|c|}{$\log _{\mathrm{e}}\left(\mathrm{P}_{\mathrm{IPO}} / \mathrm{P}_{\text {Acquisition }}\right)$} & \multicolumn{2}{|c|}{$\log _{e}\left(P_{\text {IPO }} / P_{\text {Write-off }}\right)$} & \multicolumn{2}{|c|}{$\log _{\mathrm{e}}\left(\mathrm{P}_{\text {Acquisition }} / \mathrm{P}_{\text {Write-off }}\right)$} \\
\hline & Coefficient & t-statistic & Coefficient & t-statistic & Coefficient & t-statistic & Coefficient & t-statistic & Coefficient & t-statistic & Coefficient & t-statistic \\
\hline Constant & NA & NA & NA & NA & NA & NA & -2.5698 & -1.1867 & -13.7273 & $-2.5980^{* * *}$ & -11.1575 & $-2.1085^{* *}$ \\
\hline Actual Exit Fixed Effect Dummy & -11.4204 & $-2.8731^{* * *}$ & -1.0634 & -0.4590 & 3.7302 & $1.7342^{*}$ & NA & NA & NA & NA & NA & NA \\
\hline Expected Exit Fixed Effect Dummy & -16.9251 & $-3.1318^{* \star *}$ & 3.2803 & 1.3781 & 2.8175 & 1.2394 & NA & NA & NA & NA & NA & NA \\
\hline Common Equity & 5.4714 & $2.7508^{\star \star \star}$ & -1.9620 & $-2.1279^{* *}$ & -1.4190 & -1.3666 & 1.9500 & $2.2998^{* *}$ & 2.0083 & 1.1257 & 0.0583 & 0.0355 \\
\hline Convertible Preferred Equity & -4.0235 & -1.4538 & 2.1753 & 1.2850 & 1.2988 & 1.0180 & 0.0160 & 0.0143 & -0.2876 & -0.1285 & -0.3035 & -0.1468 \\
\hline Mixed Debt Common & -2.0351 & -0.7883 & 0.8918 & 0.5287 & 2.0693 & 1.5287 & NA & NA & NA & NA & NA & NA \\
\hline Market/Book & -0.1160 & -0.9821 & 0.2491 & $1.8097^{*}$ & NA & NA & NA & NA & NA & NA & NA & NA \\
\hline Investment Months & 0.0567 & 1.2161 & -0.0289 & -0.9393 & -0.0437 & -1.4063 & 0.0386 & 1.2923 & 0.3172 & $2.4643^{* *}$ & 0.2786 & $2.1923^{* *}$ \\
\hline Biotech / Medical & -1.9163 & -1.1852 & -0.3213 & -0.2833 & -0.2606 & -0.2272 & -0.7552 & -0.6394 & -1.6825 & -0.7265 & -0.9273 & -0.4389 \\
\hline Computer / Electronics & -2.3708 & -1.2530 & -0.5583 & -0.4263 & -0.9111 & -0.5965 & -0.8145 & -0.7500 & -6.2964 & $-1.8192^{*}$ & -5.4819 & -1.6214 \\
\hline Communication / Internet & 2.5952 & 1.2931 & -1.4732 & -1.3906 & -1.4829 & -1.3761 & 0.3639 & 0.3809 & -1.0246 & -0.5295 & -1.3885 & -0.7302 \\
\hline Preplanned Exit & 2.6837 & 1.6143 & 1.3587 & 1.1694 & NA & NA & NA & NA & NA & NA & NA & NA \\
\hline Market Conditions & 3.7623 & $1.9240^{*}$ & 1.2686 & 1.0078 & NA & NA & NA & NA & NA & NA & NA & NA \\
\hline Fundraising & 4.0514 & 1.3997 & -1.3467 & -0.6136 & NA & NA & NA & NA & NA & NA & NA & NA \\
\hline VC Control Exit & 1.6307 & 0.8647 & -0.6500 & -0.3917 & -2.6024 & -1.5047 & -0.6822 & -0.4510 & 3.1364 & 1.0198 & 3.8186 & 1.1972 \\
\hline Entrepreneur Control Exit & 4.8802 & $1.9273^{*}$ & -0.6074 & -0.3371 & -5.4039 & $-2.2395^{\star *}$ & 0.7283 & 0.4453 & 8.5230 & $2.3120^{* *}$ & 7.7947 & $2.0794^{* \star}$ \\
\hline VC Board Seats > $50 \%$ & -1.5114 & -0.9165 & -0.1928 & -0.2121 & 0.9300 & 1.1042 & -0.1305 & -0.1662 & -2.5373 & -1.2599 & -2.4069 & -1.2099 \\
\hline Number VC Syndicated Partners & 1.2450 & $1.8050^{*}$ & -0.3105 & -0.6750 & 0.1009 & 0.2200 & 0.5432 & 1.2845 & 0.3429 & 0.4740 & -0.2003 & -0.2825 \\
\hline Total \# Contingencies & 3.7557 & $2.5840^{* \star \star}$ & -1.3833 & $-2.0540^{* \star}$ & NA & NA & NA & NA & NA & NA & NA & NA \\
\hline Total \# Veto Rights & -1.1096 & -1.3967 & -0.0777 & -0.1726 & NA & NA & NA & NA & NA & NA & NA & NA \\
\hline Total \# Control Rights & 0.6043 & 1.2165 & 0.3429 & 1.1320 & -0.1411 & -0.4974 & -0.0605 & -0.2307 & 1.0179 & 1.5159 & 1.0784 & $1.6529^{*}$ \\
\hline \multirow[t]{2}{*}{ Expected Exit } & NA & NA & NA & NA & NA & NA & -0.6711 & -0.9177 & 3.4547 & 1.4057 & 4.1257 & $1.6962^{*}$ \\
\hline & \multicolumn{12}{|c|}{ Predicted Outcomes } \\
\hline Actual Outcomes & No & Yes & No & Yes & No & Yes & & & IPO & Acquisition & Write-off & \\
\hline No & 44 & 5 & 24 & 9 & 52 & 4 & & IPO & 11 & 11 & 0 & \\
\hline Yes & 7 & 15 & 9 & 29 & 10 & 5 & & Acquisition & 5 & 32 & 1 & \\
\hline
\end{tabular}




\begin{tabular}{|c|c|c|c|c|c|c|c|c|}
\hline \multicolumn{9}{|c|}{ Table 12. Determinants of Returns } \\
\hline \multicolumn{9}{|c|}{ 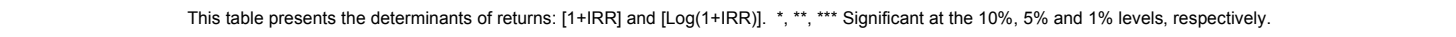 } \\
\hline \multirow[b]{4}{*}{ Explanatory Variables } & \multicolumn{8}{|c|}{ Dependent Variables } \\
\hline & \multicolumn{4}{|c|}{ Actual and Expected Exits (71 Observations) } & \multicolumn{4}{|c|}{ Actual Exits only (33 Observations) } \\
\hline & \multicolumn{2}{|c|}{ Model 1: 1+IRR } & \multicolumn{2}{|c|}{ Model 2: $\log (1+\operatorname{IRR})$} & \multicolumn{2}{|c|}{ Model 3: 1+IRR } & \multicolumn{2}{|c|}{ Model 4: $\log (1+$ IRR $)$} \\
\hline & Coefficient & t-statistic & Coefficient & t-statistic & Coefficient & t-statistic & Coefficient & t-statistic \\
\hline Constant & 1.0015 & $262.7240^{* \star *}$ & 0.0013 & 0.3565 & 1.0070 & $164.2510^{\star * *}$ & 0.0067 & 1.1269 \\
\hline IPO & 0.0198 & 4.9524*** & 0.0197 & $5.0458^{\star \star \star}$ & 0.0330 & $7.3483^{* * *}$ & 0.0326 & $7.5138^{* * *}$ \\
\hline Acquisition & 0.0215 & $6.6984^{\star \star \star}$ & 0.0213 & $6.7930^{* \star *}$ & 0.0302 & $16.4670^{* \star \star *}$ & 0.0300 & $16.8941^{* \star \star *}$ \\
\hline Book Value & $-7.4402 \mathrm{E}-08$ & -1.3169 & $-7.4011 \mathrm{E}-08$ & -1.3430 & $-1.6191 \mathrm{E}-07$ & $-2.5006^{\star \star}$ & -0.0000002 & $-2.4718^{* *}$ \\
\hline \# Rounds & 0.0022 & $1.8319^{*}$ & 0.0022 & $1.8684^{*}$ & 0.0019 & 1.4261 & 0.0019 & 1.4714 \\
\hline Seed & -0.0096 & $-2.9291^{\star \star *}$ & -0.0094 & $-2.9432^{2 * \star}$ & -0.0171 & $-4.4577^{* \star *}$ & -0.0167 & $-4.5056^{* * *}$ \\
\hline Early Stage & -0.0108 & $-2.9772^{\star \star \star}$ & -0.0106 & $-2.9879^{* * *}$ & -0.0166 & $-4.4580^{* * *}$ & -0.0161 & $-4.4963^{* * *}$ \\
\hline Expansion Stage & -0.0043 & $-1.8936^{*}$ & -0.0043 & $-1.9170^{*}$ & 0.0021 & 0.9178 & 0.0020 & 0.9084 \\
\hline Biotech / Medical & 0.0039 & 1.4925 & 0.0038 & 1.4903 & 0.0083 & $3.1960^{* * * *}$ & 0.0081 & $3.2169^{* * *}$ \\
\hline Computer / Electronic & 0.0030 & 0.9724 & 0.0029 & 0.9390 & 0.0041 & 1.0290 & 0.0040 & 1.0449 \\
\hline Communications / Internet & 0.0045 & $1.7881^{*}$ & 0.0044 & 1.7793 & 0.0133 & $3.8544^{* \star *}$ & 0.0129 & $3.8814^{* \star \star}$ \\
\hline Investment Months & 0.0000 & -0.1821 & 0.0000 & -0.2136 & -0.0001 & $-2.5085^{\star \star}$ & -0.0001 & $-2.5196^{* \star *}$ \\
\hline Common Equity & -0.0003 & -0.1716 & -0.0004 & -0.1844 & 0.0001 & 0.0500 & 0.0001 & 0.0460 \\
\hline Convertible Preferred Equity & 0.0038 & 1.6333 & 0.0037 & 1.6311 & -0.0185 & $-5.5508^{* * *}$ & -0.0181 & $-5.6266^{* * *}$ \\
\hline Mixed Debt and Common & -0.0035 & -1.5142 & -0.0035 & -1.5124 & -0.0247 & $-7.1725^{* * *+}$ & -0.0240 & $-7.2839^{* * *}$ \\
\hline Ownership \% & 0.0001 & 1.1830 & 0.0001 & 1.1715 & 0.0001 & $1.9402^{*}$ & 0.0001 & $1.9028^{*}$ \\
\hline VC Board Seats > 50\% & 0.0016 & 0.8534 & 0.0015 & 0.8441 & -0.0023 & -1.0660 & -0.0021 & -1.0201 \\
\hline Market Conditions reason for exit & -0.0087 & $-3.2586^{* \star \star *}$ & -0.0086 & $-3.2745^{* \star \star}$ & -0.0083 & $-2.9445^{* \star *}$ & -0.0082 & $-2.9911^{* * * *}$ \\
\hline Preplanned Exit & -0.0011 & -0.3293 & -0.0011 & -0.3491 & -0.0067 & $-2.3780^{* *}$ & -0.0066 & $-2.4371^{* *}$ \\
\hline Total Number of Contingent Contractual Clauses & 0.0009 & 0.9627 & 0.0009 & 0.9677 & -0.0030 & -0.7789 & -0.0032 & -0.8648 \\
\hline Total Number of Veto Right Clauses & 0.0006 & 0.6567 & 0.0006 & 0.6560 & 0.0145 & $5.7843^{* * *+}$ & 0.0141 & $5.8277^{* * * *}$ \\
\hline Total Number of Control Right Clauses & -0.0024 & $-3.6880^{* * *}$ & -0.0023 & $-3.7128^{* * *}$ & -0.0103 & $-6.9231^{* * *}$ & -0.0101 & $-7.0098^{* * *}$ \\
\hline Expected Exit & -0.0143 & $-3.7886^{* * *}$ & -0.0141 & $-3.8172^{\star \star \star *}$ & NA & NA & NA & NA \\
\hline Adjusted $\mathrm{R}^{2}$ & & & & & & & & \\
\hline
\end{tabular}




\title{
ENDNOTES
}

\begin{abstract}
${ }^{1}$ The term 'venture capital' is defined differently across countries. In this paper we employ the definition used by the European Venture Capital Association (www.evca.com), which is inclusive of seed, early, expansion, mezzanine (late), turnaround and buyout transactions. This broad definition is also used in other jurisdictions such as Canada (www.cvca.ca). Regardless, the main results in this paper are not contingent on the particular definition of venture capital. As well, all of the (self-described) venture capital funds in the data herein consider financing different types of entrepreneurial firms.
\end{abstract}

${ }^{2}$ Venture capitalists may also dispose of their investments via a secondary sale (where the venture capitalist sells to a third party, but the entrepreneur retains his or her interest), a buyback (where the entrepreneur repurchases the venture capitalist's interest), or a write-off (liquidation); see MacIntosh (1997). Partial dispositions through each exit vehicle are also possible (Cumming and MacIntosh, 2002).

${ }^{3}$ The term 'acquisition' generally refers to trade sales to other investors as well as other strategic acquirors. Acquisitions pertain to strategic acquirors in the data herein.

${ }^{4}$ Schweinbacher (2002) considers VC exits in Europe, but the data are averaged at the VC fund level (no investment specific data were collected).

${ }^{5}$ This list omits papers pertaining to VC fundraising and fund structure (see, e.g., Jeng and Wells, 2000; Gompers and Lerner, 1996, 1998, 1999; and Mayer et al., 2002). Please advise the author as to missing citations.

${ }^{6}$ U.S. based research on this issue has only considered limited partnerships. Future research in the U.S. could consider other types of venture capital funds as well. In addition, future theoretical research may attempt to explain forms of finance other than convertible preferred equity, in light of the fact that the only evidence that convertible preferred equity is used most frequently is from U.S. data. Some recent theoretical papers provide guidance as to the use of different securities by venture capitalists; see Garmaise (2000), Chemmanur and Chen (2002) and Schindele (2002). 
${ }^{7}$ Gilson and Schizer (2002) note that failed start-ups typically "owe back-rent for office space, payroll, and other liabilities" (page 11). They also note that failed start-ups typically do not file for bankruptcy, a proceeding that is worthwhile only when there are remaining assets to be divided up (Gilson and Schizer, 2002, footnote 21).

${ }^{8}$ See Cumming (2000) for evidence from Canada, Songtao (2000) for evidence from Taiwan, Smith and Parahangus (2000) for evidence from Finland, Bascha and Walz (2001) for evidence from Germany, as well as the Australian Bureau of Statistics. As well, note that U.S. VCs finance Canadian entrepreneurial firms with a variety of forms of finance (Cumming, 2001). Unfortunately, direct tests of functional equivalence are not possible with any of these datasets. For example, with a sample of Canadian venture capitalist data, Cumming (2000) provides tests of functional equivalence be grouping various securities together and considering whether groups of securities are used with the same intensity for similar transaction types. Cumming, however, cannot directly test for functional equivalence across securities with the underlying transactional terms.

9 This supports recent theoretical research indicating riskier claims are associated with less control. In Cestone's model, the intuition is based on the idea that formal control with common equity would turn into excessive real control (over interference) because VCs have greater incentives to intervene with riskier claims (Cestone, 2000, p.15). Kaplan and Strömberg, 2002, similarly find that different control rights are complementary, not substitutes, in the U.S. where convertible preferred equity is typically the selected security.

${ }^{10}$ A dummy for non-tech industries was suppressed to avoid collinearity. These three industry categories were most appropriate for the given observations in the data, and the characteristics of the investments within each of these three groups were most similar.

${ }^{11}$ To the extent that data were available, voting \% was nearly perfectly correlated with ownership $\%$; therefore, separate tests are not provided.

12 The dependent variables for models 4 and 5 are bounded (between 0 and 1). Alternative econometric specifications did not materially affect the results. 
13 Trilateral bargaining describes an agency where the entrepreneur has an incentive to give up control over the firm to an outside investor (after contracting with the initial investor) in order to lower the firm's cost of capital; see Aghion and Bolton (1992) and Berglöf (1994).

14 'Expected exits' (typically close to the exit date) are not the same thing as 'preplanned exits' (at time of contract).

15 See also Table 3.b. These results are not affected by correlation among variables. For example, dropping the variables for control rights, veto rights and contractual contingencies does not affect the significance of other variables.

${ }^{16}$ The relation between investment duration, market/book ratios and the likelihood of different exit outcomes was first studied by MacIntosh (1997), and follow-up work by Cumming and MacIntosh (2002, 2003). MacIntosh (1997) and Cumming and MacIntosh (2002, 2003) find firms with higher market/book ratios are more likely to go public.

${ }^{17}$ See also Smith and Smith (2000). Published research by MacIntosh (1997) and Cumming and MacIntosh (2002) indicates selection effects associated with a more complete set of exit vehicles (IPOs, acquisitions, secondary sales, buybacks, and write-offs, as well as the extent of exit (full or partial). Cumming and MacIntosh (2002, 2003) provide extensions to MacIntosh's (1997) seminal paper.

${ }^{18}$ Returns may also depend on the characteristics of the investor. With the actual number of exits (33), we do not have a large number of degrees of freedom to use investor fixed effect dummies to test this proposition jointly with the other variables. Nevertheless, with different regressions (not presented), investor fixed effects did not appear to be a significant factor in explaining IRRs in this data sample. Other model specifications (e.g., different transformations of the variables using Box-Cox methods, etc.) did not materially change the results.

${ }^{19}$ These categories are based on Kaplan and Stromberg (2002).

${ }^{20}$ These examples are based on Sahlman et al. (1999). The venture capitalists participating in this study did not want any of their actual contracts to appear in public print. 